\title{
Current Account Adjustment and Retained Earnings
}

Andreas M. Fischer, Henrike Groeger, Philip Sauré and Pinar Yeşin

\section{Globalization Institute Working Paper 345}

Research Department

https://doi.org/10.24149/gwp345

Working papers from the Federal Reserve Bank of Dallas are preliminary drafts circulated for professional comment. The views in this paper are those of the authors and do not necessarily reflect the views of the Federal Reserve Bank of Dallas or the Federal Reserve System. Any errors or omissions are the responsibility of the authors. 


\title{
Current Account Adjustment and Retained Earnings*
}

\author{
Andreas M. Fischer ${ }^{\dagger}$, Henrike Groeger ${ }^{\ddagger}$, Philip Sauré ${ }^{\S}$ and Pinar Yeşin ${ }^{ \pm}$
}

August 2018

\begin{abstract}
This paper develops a formal strategy to calculate current accounts with retained earnings (RE) on equity investment and analyzes their adjustment during the global financial crisis. RE are the part of companies' profits which are reinvested and not distributed to shareholders as dividends. International statistical standards treat $\mathrm{RE}$ on foreign direct investment and RE on portfolio investment differently: while the former enter the current and financial account, the latter do not. We show that this differential treatment strongly affects current accounts of several advanced economies, frequently referred to as financial centers, with large positions in equity (portfolio) investment. Our empirical analysis finds that the differential treatment of RE alters the interpretation of current account adjustment for the global financial crisis.
\end{abstract}

Keywords: Current account adjustment, financial centers, retained earnings, equity investment

JEL Classification Number: F32, F47, G11

\footnotetext{
* This project was initiated through numerous conversations with Thomas Schlup. The authors would like to thank Alex Flühmann, Robert Kollmann, Gian Maria Milesi-Ferretti, Stefan Zeugner, and especially our discussant Gaëtan Nicodème for comments on a previous draft as well as participants at the SNB Brownbag Seminar, the Global Financial Flows Workshop at the IMF, the BIS-SNB workshop, the Annual Congress of the Swiss Society of Economics and Statistics, the JIMF Brussels Conference. Chloe Larkou and Anna Raafat provided valuable research assistance. Any remaining errors are our own. The views expressed in this paper are those of the authors and not necessarily those of the Swiss National Bank, the Federal Reserve Bank of Dallas and the Federal Reserve System.

${ }^{\dagger}$ Andreas M. Fischer, Swiss National Bank and CEPR, andreas.fischer@snb.ch.

${ }^{\ddagger}$ Henrike Groeger, European University Institute, henrike.groeger@eui.eu.

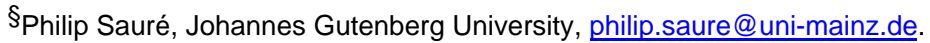

${ }^{ \pm}$Pinar Yeşin, Swiss National Bank, pinar.yesin@snb.ch.
} 
"... because reinvested earnings are recorded only for equity in direct investment and investment funds, but not for other types of equity, it may be useful for some analysis to have measures of income and the current account with and without reinvested earnings."

Paragraph 11.41 in International Monetary Fund (2009)

\section{Introduction}

Recent studies argue that large wealth transfers materialized during the global financial crisis (GFC) 1 In particular, Gourinchas et al. (2012) show that equity (portfolio) investment was an important channel through which these transfers materialized.2 Indeed, the buildup of U.S. equity investment was particularly strong prior to the global financial crisis (GFC), and so was its reversal during the GFC. If dividend flows on equity investment are smoother than retained earnings (RE) on equity investment during crisis periods, then a large part of the wealth transfers is accounted for by RE. The incomplete recording of RE in the current account according to standard accounting principles (see above quotation) therefore implies that the large wealth transfers that materialized during the GFC may not have been fully captured in the current account. Taken together, these observations suggest that the current account is possibly an incomplete indicator of external adjustments. While this drawback is not worrisome per se, it becomes important as soon as the current account is used as an indicator of global imbalances $3^{3}$

This paper develops a formal strategy to calculate corrected current accounts with RE on equity investment and then analyzes the behavior between the official current account and the corrected current account with RE during the GFC. The strategy first proxies country-specific payout ratios according to national stock markets. It then combines this information with bilateral positions of equity in-

\footnotetext{
${ }^{1}$ See, e.g., Gourinchas et al. (2012), McCauley and McGuire (2009), and McGuire and Goetz (2009).

${ }^{2}$ Portfolio investment is divided into debt and equity investment. Hereafter, we will refer only to equity investment.

${ }^{3}$ See, e.g., Lane and Milesi-Ferretti (2012). Obstfeld (2012) writes that "global current account imbalances remain an essential target for policy scrutiny, for financial as well as macroeconomic reasons."
} 
vestment to assess the size of $\mathrm{RE}$ in the respective cross-border equity investment. Summing a country's bilateral RE and netting over foreign assets and liabilities then yields the corrected current account with RE.

The empirical analysis provides estimates of current accounts with RE for 44 countries from 2001 to 2015. The data coverage is extensive; it accounts for $82 \%$ of world GDP and $87 \%$ of the world's total equity investment in assets. The RE correction is computed for 627 country-year pairs.

The paper then presents two sets of empirical findings. First, the estimated $\mathrm{RE}$ are time-varying and large for the so-called financial centers (defined as Hong Kong, Ireland, Norway, and Switzerland) 4 Figure 1 shows that, in 2015, these countries had equity assets plus liabilities exceeding 150\% of GDP and net equity positions exceeding $50 \%$ of GDP in absolute terms. $5^{5}$ We estimate that the absolute value of the RE on average ranges from 1.2 to $7.8 \%$ of GDP for these countries. On the other hand, the estimated RE are small for emerging market economies.

The second finding is that the corrected current accounts with RE clearly illustrate how global imbalances adjusted during the GFC. The analysis finds that countries with large net equity imbalances experienced exceptionally large current account adjustments. This result is explained by the behavior of international equity markets during the crisis period. Before the GFC, equity markets experienced large corporate profits and therefore large transfers in RE. As the crisis unfolded, however, corporate profits fell sharply and RE remained small. This implied that economies that were highly financially integrated experienced larger adjustments in income flows in equity investment than the global average. This interpretation of adjustment in global imbalances through financial markets complements the narrative of Lane and Milesi-Ferretti (2012), who argue that the adjustment of global imbalances occurred through trade balances and that countries with exchange rate pegs were especially affected.

\footnotetext{
${ }^{4}$ The literature on financial centers uses numerous definitions. The IMF defines Belgium, Hong Kong SAR, Luxembourg, Netherlands, Singapore, and Switzerland as financial centers. These "economies that serve as hubs for international financial flows have tended to run substantial current account surpluses and net creditor positions," see Lee et al. (2008).

${ }^{5}$ Chile is another country which has a large net balance position, but is not included in our group of financial centers because it does not fulfill the size criteria of equity assets plus equity liabilities greater than $70 \%$ of GDP.
} 
Figure 1: Equity positions of the financial centers in our sample
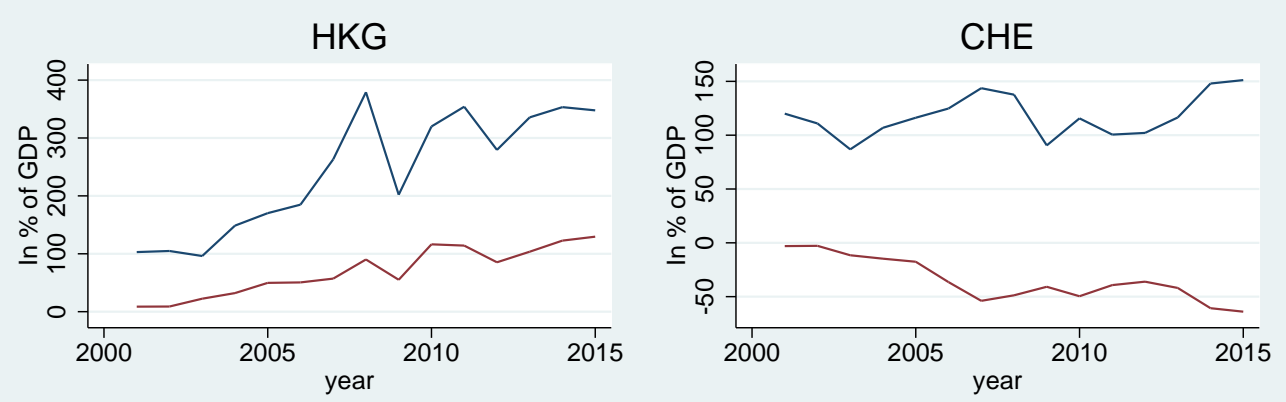

IRL
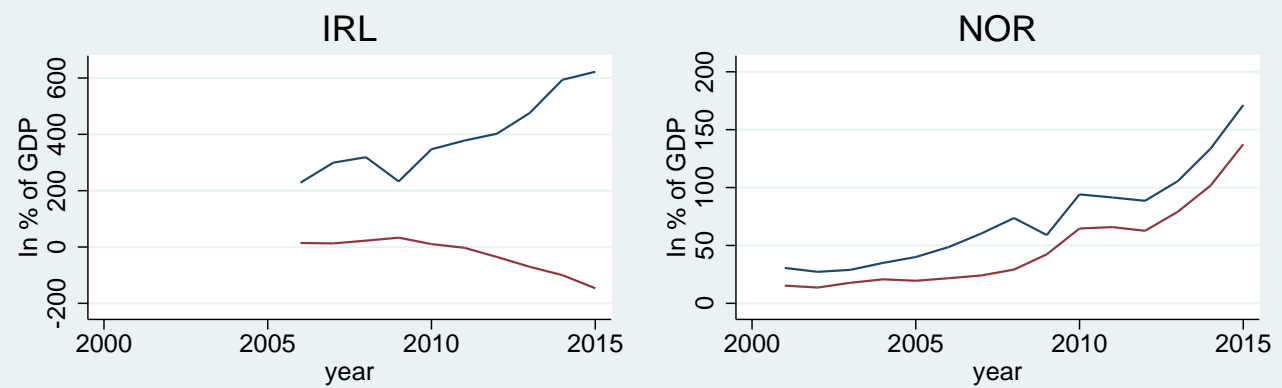

SIZE (blue): equity investment position = (assets + liabilities $) / G D P$

IMBALANCE (red): net equity investment = (assets - liabilities)/GDP

Source: IMF CPIS, IMF BOPS, own calculations 
Our research is related to a broader set of questions that asks how income, multinational firms, and external balances are related. One strand of the literature highlights the special role of financial centers in international finance, see Caballero et al. (2016), Chinn and Ito (2006), Gourinchas and Rey (2007), and others. Lee et al. (2008) note that financial centers serve as hubs for international financial transactions and tend to run substantial current account surpluses. Our findings show that financial centers with large net equity liabilities are heavily affected by the RE correction and that their current accounts need to be revised downward.

Another strand of the literature of high policy relevance emphasizes measurement issues when considering global policy issues for external adjustment $]^{6}$ The International Monetary Fund's (IMF) exchange rate assessments, for example, published in the IMF External Sector Report, rest heavily on whether a country's current account is consistent with fundamentals 7 If the differential treatment of RE distorts a country's current account, this in turn could influence the policy analysis. A further multilateral implication of the RE correction is that it can distort the GNI, the base on which EU member countries calculate their contributions to the EU budget 8 Our cross-country estimates for current accounts with $\mathrm{RE}$ are also the first to show that a policy bias may arise for several countries if the $\mathrm{RE}$ correction is persistent in one direction. 9

This paper is organized as follows. Section 2 motivates the need to consider current accounts with RE on equity investment. Section 3 presents the strategy to calculate RE. Section 4 discusses data and documents statistical properties of the RE estimates. Section 5 documents the empirical analysis of the RE correction for medium-term exchange rate models. Section 6 concludes.

\footnotetext{
${ }^{6}$ See Curcuru et al. (2010), Curcuru et al. (2013), and Obstfeld (2012).

${ }^{7}$ For example, see the discussion of Switzerland in the International Monetary Fund (2016), 53-54.

${ }^{8}$ See the "own resource" section at http://ec.europa.eu/budget/explained/budg_ system/financing/fin_en.cfm for further details.

${ }^{9}$ Separate but equally important measurement issues affecting the interpretation of the current account for individual countries include valuation effects, see Devereux and Sutherland (2010) and Mian and Sauré (2018); global production arrangements, see Beusch et al. (2017); and return on international assets, see Gourinchas and Rey (2007).
} 


\section{Current accounts with retained earnings}

Income from foreign direct investment and income from foreign equity investment have become increasingly important components of the current account for several countries because of the increasing size of their international investment positions. In particular, equity investment has increased considerably in the last two decades. Table 1 records the degree of financial openness with respect to equity investment for ten countries. Financial openness is defined as assets plus liabilities in equity investment divided by GDP. The table shows that between 2003 and 2015, financial openness has more than doubled for numerous advanced economies.

In light of the growing international positions of equity investment, it is important to note that international statistical standards, namely the Balance of Payments Manual 6 (BPM6), treat RE on equity and foreign direct investment differently. RE are defined as the part of income that is not paid out to investors via dividends. $\mathrm{RE}$ that accrue from direct investments and investment funds are recorded as investment income in the current account and the financial account. But RE on equity investment are not counted as investment income, and thus enter neither the current account nor the financial account. This differential treatment in international accounting rules can severely impact a country's current and financial account ${ }^{10}$ It is recognized that the accounting practice regarding $R E$ may be contentious. Nevertheless, there have been no formal attempts to correct for $\mathrm{RE}$ on equity investment for a wide set of countries 11

There are several channels in which RE may affect a country's external bal-

\footnotetext{
${ }^{10}$ The reason for including reinvested earnings in FDI is given in 11.41 in International Monetary Fund (2009): "The rationale behind the treatment of reinvested earnings on direct investment is that, because a direct investment enterprise is, by definition, subject to control, or influence, by a direct investor or investors, the decision to retain and reinvest some of its earnings within the enterprise represents an investment decision on the part of the direct investor(s). Many factors may influence the decisions of direct investors on the proportions of net earnings of direct investment enterprises to be distributed or retained, including taxation systems, transfer costs, investment opportunities in the ongoing business and elsewhere, relative costs of moving financial resources, and need to expand the ongoing business." There is a difference in the status of portfolio and direct investors. A direct investor has a $10 \%$ minimum shareholder ownership of the company, and can possibly exert influence on the distribution of profits. However, a portfolio investor with equity investment has an ownership level below $10 \%$.

${ }^{11}$ (Swiss National Bank, 2006, pp 26-27) quantifies the RE correction for Switzerland. Eggelte et al. (2014) quantify the RE correction for the Netherlands.
} 
Table 1: Financial openness (top ten countries in 2015)

$2003 \quad 2007 \quad 2015$

top ten (\% of GDP)

\begin{tabular}{lrrr}
\hline Ireland & & 299.36 & 622.09 \\
Hong Kong & 96.18 & 263.18 & 347.73 \\
Norway & 28.91 & 60.31 & 171.29 \\
Switzerland & 86.82 & 143.68 & 151.16 \\
Netherlands & 79.37 & 100.25 & 137.88 \\
United Kingdom & 54.13 & 90.74 & 117.19 \\
Denmark & 23.79 & 55.94 & 99.13 \\
Sweden & 37.15 & 76.87 & 97.06 \\
Canada & 33.49 & 58.80 & 94.84 \\
South Africa & 26.41 & 44.76 & 85.38
\end{tabular}

Source: IMF CPIS, IMF BOPS, own calculations (see the Appendix)

Notes:

- Financial openness is defined as assets plus liabilities in equity investment divided by GDP (in percent)

(equivalent to the SIZE variable, defined in section 5 .

- Empty cells represent missing values.

ances and complicate the interpretation of current account adjustment. A first channel is a pure composition effect. Countries with large foreign net liabilities in equity investment tend to overstate their current account balance because only dividends and not RE are attributed to foreign shareholders. Figure 2 illustrates countries with sizable net asset or net liability positions in equity investment. A second channel is through large differences in the average payout ratios for dividends between countries. If firms in a particular country pay out less in dividends to foreign and domestic investors than the global average and retain a larger share of their earnings for investment, then this will overstate a country's current account. Figure 3 shows that there are large differences in the dividend payout ratios between firms within financial centers and within major economies. Moreover, some firms, such as those in Switzerland, show a clear rising trend in the dividend payout ratio over the last ten years. For other firms, such as those in the United States, there is no identifiable change in trend. Differences in trends in the payout ratios would suggest that the aggregate $\mathrm{RE}$ correction between countries should also have a trend. Furthermore, the timing of the profit collapse linked 
to the financial crisis (i.e., reflected in the sharp spike in the payout ratio) is not homogenous. The spike for the United States occurs in 2007, while for Japan it is in $2009{ }^{12}$ Such differences related to key events suggest that the RE correction on equity investment could influence the dynamics of current accounts.

Corporate taxes are frequently mentioned as driving foreign investment decisions. Studies by Blanchard and Acalin (2016), Curcuru et al. (2013), Rose and Spiegel (2007), and International Monetary Fund (2000) argue that large FDI and portfolio investments in so-called financial centers are driven by low corporate taxes. Figure 4 plots a country's corporate tax rates against the size of assets and liabilities and the net balance of equity investment. The scatter plots present suggestive evidence for the nexus between tax rates and portfolio investment: equity investment is particularly large in the low-tax jurisdictions of Ireland, Hong Kong, and Switzerland. However, the figure also suggests that taxes are not the sole determinant of equity investment positions. In the next section, we present a strategy to calculate the RE correction that is independent of assumptions for corporate taxes.

\section{$3 \quad$ Strategy to calculate retained earnings}

This section defines the strategy to calculate the RE correction on equity investment. To highlight the issues concerning the RE correction, assume for simplicity that in a world of $n=1, \ldots, N$ countries, there is one company in each country. These companies issue stocks which can be purchased from both domestic and foreign investors. The share of ownership of country $i$ 's company acquired through equity by investors from country $j$ is

$$
E_{j i} \equiv \frac{x_{j i}}{x_{i}}
$$

\footnotetext{
${ }^{12} \mathrm{~A}$ payout ratio above $100 \%$ implies that the firm is unable to pay out its dividends with its current yearly net income. The firm is required to use a different financing method, such as taking a credit or using its cash reserves. It is also important to note that share buybacks are implicitly included in the dividend payout ratios.
} 
Figure 2: Large net cross-border equity position countries in 2015
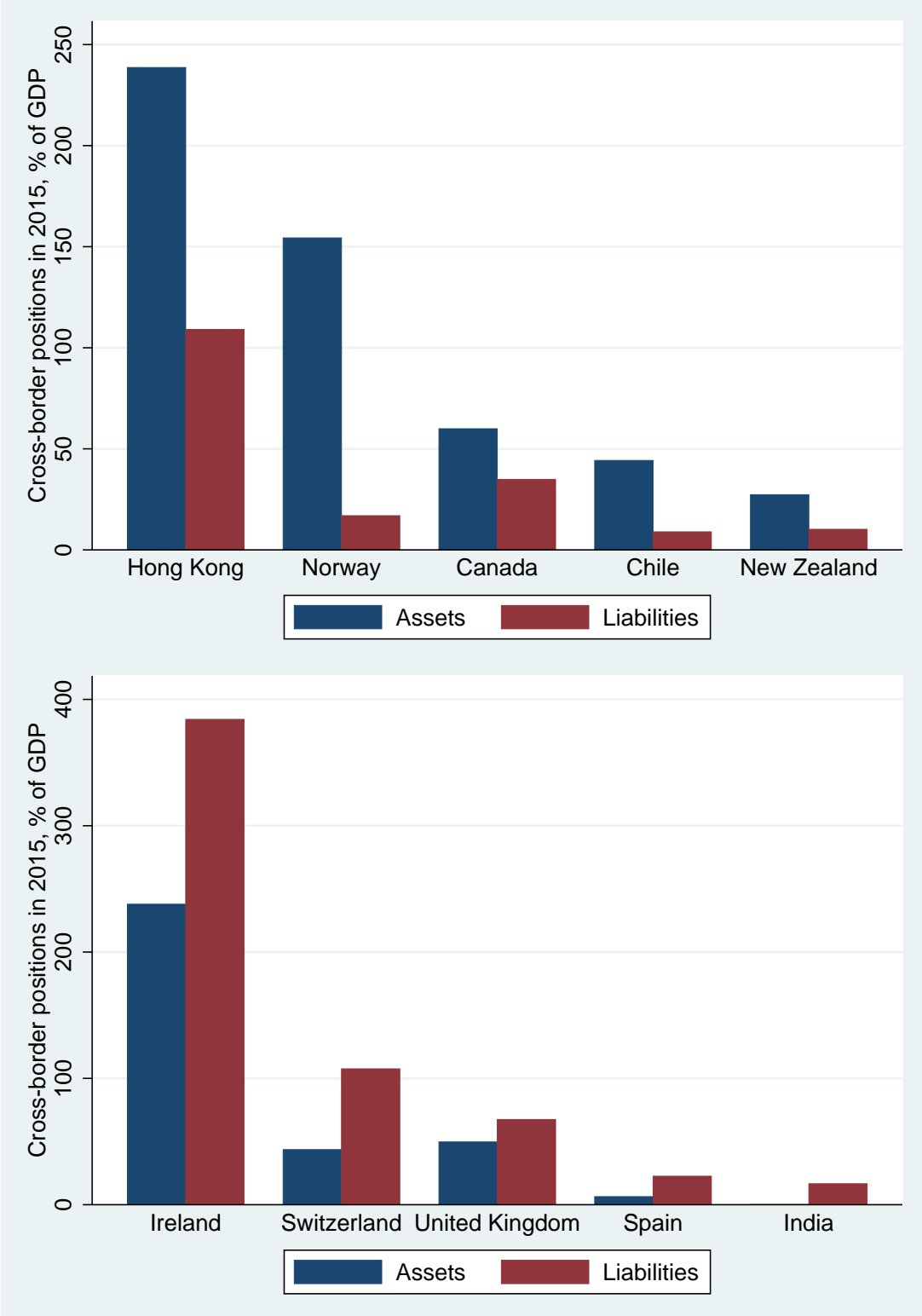

Source: IMF CPIS, IMF BOPS, own calculations (see Appendix) 
Figure 3: Dividend payout ratios for the financial centers in our sample and some major economies

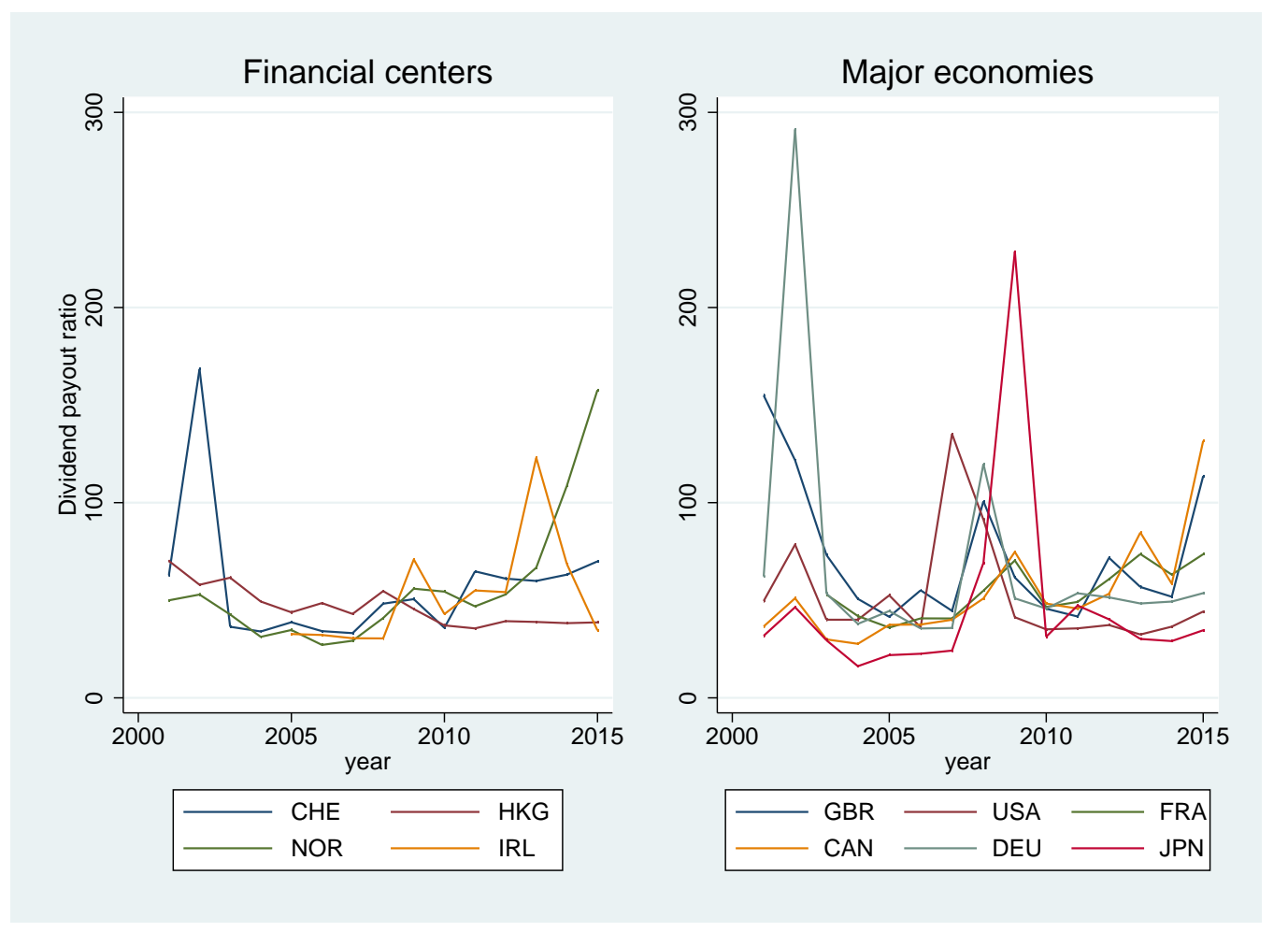

Source: Bloomberg 
Figure 4: 2015 correlation between corporate taxes and equity investments of assets and liabilities (SIZE), and net equity investments (IMBALANCES)
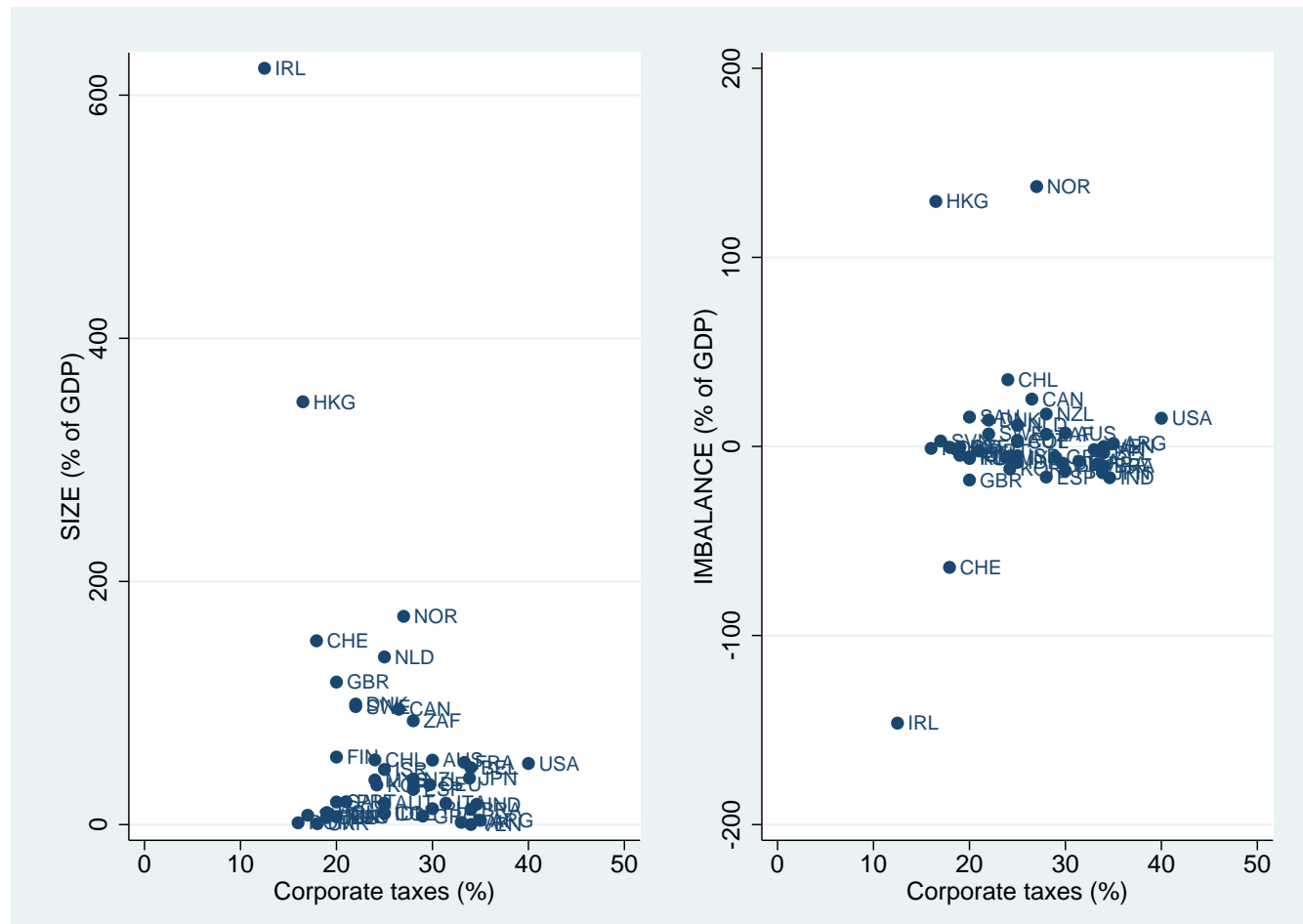

Source: KPMG, own calculations 
where $x_{i} \equiv \sum_{n=1}^{N} x_{n i}$ is the total market value of the equity issued by company $i$. The share of foreign ownership of company $i$ 's stock is defined as

$$
E_{i} \equiv \sum_{n \neq i} E_{n i}
$$

From profit $\pi_{i}$, company $i$ pays out dividends $d_{i}$ to its shareholders. The countryspecific payout ratio is defined to be $\rho_{i} \equiv \frac{d_{i}}{\pi_{i}}$. The part of profits which is not paid out as dividends is reinvested into the company as retained earnings $r_{i} \equiv$ $\pi_{i}-d_{i}=\pi_{i}\left(1-\rho_{i}\right)=d_{i} \frac{1-\rho_{i}}{\rho_{i}}$. Distinguishing between dividends paid to domestic and foreign shareholders gives

$$
d_{i}=E_{i} d_{i}+\left(1-E_{i}\right) d_{i}=d_{i}^{f}+d_{i}^{h},
$$

where $d_{i}^{f}$ are the cross-border dividend payments of company $i$ to its foreign shareholders. Correspondingly, dividend income of investors from country $i, d_{i}$, can be divided into income from abroad and income from the home company:

$$
d_{. i} \equiv \sum_{n \neq i} E_{i n} d_{n}+\left(1-E_{i}\right) d_{i} \equiv d_{. i}^{f}+d_{i}^{h}
$$

Building on (3), RE payments from company $i, r_{i}$, can be divided into those attributable to foreign investors and to domestic investors:

$$
\begin{aligned}
& r_{i}=\left(d_{i}^{f}+d_{i}^{h}\right) \frac{1-\rho_{i}}{\rho_{i}} \\
& =d_{i}^{f} \frac{1-\rho_{i}}{\rho_{i}}+d_{i}^{h} \frac{1-\rho_{i}}{\rho_{i}} \\
& \equiv r_{i}^{f}+r_{i}^{h} .
\end{aligned}
$$


RE paid to foreign investors $r_{i}^{f}$ are the correction to be made on the debit side of country $i$ 's current account, as a part of the "outgoing" investment income.

To obtain the corresponding correction on the credit side of country $i$ (as "incoming" investment income), the RE obtained by investors in country $i, r_{. i}$, can be divided in correspondence to (4):

$$
\begin{aligned}
& r_{. i}=\sum_{n \neq i} E_{i n} r_{n}+\left(1-E_{i}\right) r_{i} \\
& =\sum_{n \neq i} E_{i n} d_{n} \frac{1-\rho_{n}}{\rho_{n}}+\left(1-E_{i}\right) d_{i} \frac{1-\rho_{i}}{\rho_{i}} \\
& =\sum_{n \neq i} \frac{E_{i n}}{E_{n}} E_{n} d_{n} \frac{1-\rho_{n}}{\rho_{n}}+d_{i}^{h} \frac{1-\rho_{i}}{\rho_{i}} \\
& =\sum_{n \neq i} \frac{E_{i n}}{E_{n}} d_{n}^{f} \frac{1-\rho_{n}}{\rho_{n}}+d_{i}^{h} \frac{1-\rho_{i}}{\rho_{i}} \\
& \equiv r_{. i}^{f}+r_{i}^{h},
\end{aligned}
$$

with $\frac{E_{j i}}{E_{i}}$ being the share of country $j$ investors in the foreign-owned equity of company $i$. The correction on the credit side is $r_{. i}^{f}$. For any country $i$, the RE correction is thus calculated as the net correction

$$
R E_{i}=r_{. i}^{f}-r_{i}^{f}
$$

Therefore, the corrected current account balance is defined as

$$
C A_{i}^{\text {corrected }}=C A_{i}^{\text {official }}+R E_{i} .
$$

In other words, a positive correction indicates that the country's current account balance is higher when it is corrected for the asymmetric treatment of RE.

Next, to relax the assumption of only one company present in each country, we need the following assumption: investments by foreign stockholders from a given 
source country $i$ are allocated in a given target country $j$ in such a way that the payout ratio is on average the same as the payout ratio on investments by domestic stockholders in the target country:

$$
\text { Assumption }: \rho_{j}^{i}=\rho_{j}^{j}=\rho_{j} \text {. }
$$

The treatment of investment funds is a further issue to consider. Often, investors do not invest in equity directly but in investment funds, which in turn invest in different assets including equity and debt. These funds constitute an additional "layer" for our approach, in that the aim is to attribute the RE of investments undertaken by investment funds to the shareholders of the fund. While funds themselves divide their earnings between dividends and RE, these RE are accounted for under current accounting standards as income flows to shareholders which are then deemed to be reinvested ${ }^{13}$ Overall, the relevant accounting standards imply that capital flows channeled through investment funds do not generate a correction in the current account. Our methodology for the RE correction correctly excludes the earnings through investment funds 14

\section{Data}

We rely on three data sources to compute RE on equity investment. First, countryspecific and time-varying payout ratios $\rho_{i t}$ are taken from Bloomberg for each country's leading market index.15 Secondly, cross-border dividend payments $d_{i t}^{f}$ are taken from each country's BoP as provided in the IMF's Balance of Payments

\footnotetext{
${ }^{13}$ Paragraph 11.38 in BPM6 explains the reasoning as follows: "The net earnings of investment funds after deducting the operating expenses belong to shareholders. When only a part of the net earnings is distributed to shareholders as dividends, the RE should be treated as if they were distributed to the shareholders and then deemed reinvested."

${ }^{14}$ The Data section in the Appendix discusses how we work with the bilateral equity position data including investment funds.

${ }^{15}$ The list of indexes is included in the Appendix. The relevant time series used is DVD_PAYOUT_RATIO, which is computed as 100* IS_TOT_CASH_COM_DVD/INC_BEF_XO_LESS_MIN_INT_PREF_DVD. Exact definitions of these variables are included in the Appendix. End-of-year values are taken.
} 
Statistics (BOPS) database ${ }^{16}$ We use dividend payment expenses data on equity investment for most countries and years in the sample. However, for some countryyear pairs, only dividend payment data on equity investment and investment fund shares are available. In the latter case, our RE estimates can be viewed as an upper or lower bound estimate. Specifications for these different scenarios are available in the Appendix. Thirdly, time-varying shares of foreign investment $\frac{E_{j i t}}{E_{i t}}$ are calculated using the IMF's Coordinated Portfolio Investment Survey (CPIS). 17 The data available in these three sources allows us to obtain a set of 44 countries for which at least one RE correction - and hence one current account correction can be computed.

The source of the official current account data is the IMF BOPS, and the Swiss National Bank (SNB) for the Swiss current account. The source for country GDP data is the World Bank World Development Indicators (WDI), and SNB for Switzerland.

A possible shortcoming of the RE correction lies in the number of countries in our empirical sample. The annual sample of 44 countries includes 26 major advanced economies ${ }^{18}$ and 18 emerging market economies ${ }^{19}$ This means that we are unable to fully attribute all dividend flows and RE to the proper foreign investors. However, as will be shown below, the financial linkages for equity investment are strongest between advanced economies. Therefore, the limited number of emerging market economies does not result in a serious shortcoming.

Figure 5 offers a consistency check in that it aggregates RE to domestic investors, $r_{. i}^{f}$, and subtracts the $44 \mathrm{RE}$ paid to foreign investors $r_{i}^{f}$ (i.e., the correc-

\footnotetext{
${ }^{16}$ Although these data are in principle available for Switzerland, they are not included in the IMF BOPS database. The SNB data are therefore converted to U.S. dollars and included in our data set. The exact time series of interest are in a subcomponent of the current account called dividends on equity (dividends on equity excluding investment fund shares, whenever available), and are recorded under investment income on equity and investment fund shares.

${ }^{17}$ Further information on the IMF CPIS data set is also available in the Appendix.

${ }^{18}$ Based on the IMF categorization of advanced economies.

${ }^{19}$ The 44 countries are Argentina, Australia, Austria, Belgium, Brazil, Canada, Chile, Colombia, Czech Republic, Denmark, Finland, France, Germany, Greece, Hong Kong, Hungary, India, Indonesia, Ireland, Israel, Italy, Japan, Korea, Malaysia, the Netherlands, New Zealand, Norway, Pakistan, Philippines, Poland, Portugal, Romania, Russian Federation, Saudi Arabia, Slovenia, South Africa, Spain, Sweden, Switzerland, Turkey, Ukraine, the United Kingdom, the United States, and Venezuela.
} 
Figure 5: Multilateral consistency

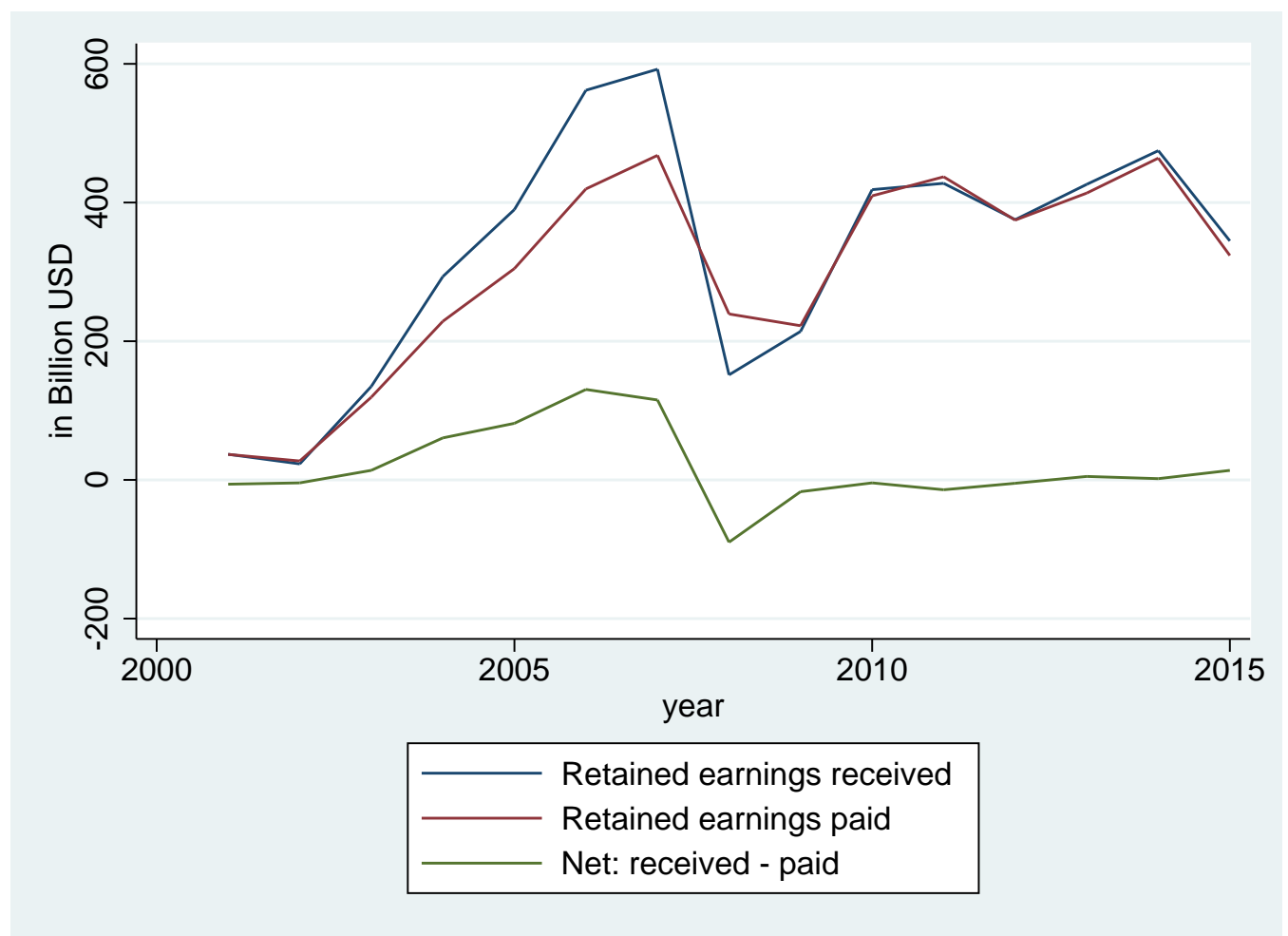

Source: Own calculations

tion to be made on the debit side of country $i$ 's current account). If our country coverage is adequate, the aggregate difference should be zero. The green line in Figure 5 shows that this is indeed the case, especially for the latter half of our sample period, suggesting that our measurement of the RE correction is multilaterally consistent.

Figure 5 also shows that the aggregate $r_{. i}^{f}$ and $r_{i}^{f}$ are highly procyclical over the global business cycle. This suggests that the corrections for individual countries were smallest during the GFC and largest immediately before and after. The fact that the aggregate $r_{. i}^{f}$ and $r_{i}^{f}$ are smallest at sample begin should not be interpreted to suggest that the RE correction is a recent phenomenon. Rather, it simply reflects the fact that we have less country coverage at the sample's beginning than at the sample's end. 
Table 2 shows the mean, variance, minimum value, and maximum value over time of the incoming RE correction in terms of GDP for the ten largest and smallest source countries. The incoming RE correction refers to the share of RE generated in all destination countries that should be attributed to the shareholders in the source country. All of the financial center countries are in the top ten countries. The variance of $7.5 \%$ with respect to GDP for Ireland stands out against the other countries ${ }^{20}$ The bottom ten countries are all emerging market economies and have little or no RE on foreign assets.

Table 3 shows the same information, but now for the outgoing RE on foreign liabilities. Again, the financial centers are prominent in that three of the four are in the top ten countries and Norway is in the bottom ten countries. Ireland maintains the largest position with a mean of $10.3 \%$ with respect to GDP. The bottom ten countries are again dominated by emerging market countries.

Table 4 presents the position for RE correction on equity investment. This is defined as the net position from incoming minus outgoing RE. The table shows that Norway has the largest positive mean position; Ireland, Hong Kong, Russia, and Korea have the largest mean negative positions. We should recall that a positive correction results in an upward correction of the current account and, similarly, a negative correction results in a downward correction of the current account.

The RE correction exhibits large cross-country variations during the sample period. Figure 6 illustrates this point by plotting the min-max ranges from 2001 to $2015{ }^{21}$ In particular, it shows that there was considerable cross-country variation before the buildup to the financial crisis, and thereafter it collapses sharply. This behavior is reflective of the fact that corporate profits of international firms collapsed during the GFC.

\footnotetext{
${ }^{20}$ It is well known that the Irish BoP data suffer from numerous anomalies, see Fitzgerald (2013) and Lane (2014). A particular issue for the Irish RE estimate concerns the high share of investment funds. The Appendix explains that the presence of investment funds in Ireland does not impact our estimation directly, because equity position data are not directly used in our methodology. On the other hand, we rely heavily on data on portfolio equity dividend flows to and from Ireland in the estimation. As long as they are correctly captured in all countries' official current account statistics, our RE estimates will be reliable.

${ }^{21}$ Further statistics on the corrected current accounts with $\mathrm{RE}$ are given in the Appendix.
} 
Table 2: Retained earnings on assets (top ten and bottom ten countries) (\%GDP)

Mean Variance Min Max

top ten

\begin{tabular}{lrrrr}
\hline Ireland & 7.47 & 7.52 & 1.14 & 10.96 \\
Hong Kong & 2.71 & 2.93 & 0.03 & 5.43 \\
Switzerland & 2.54 & 5.29 & -0.10 & 7.73 \\
Netherlands & 2.13 & 0.94 & 0.27 & 3.63 \\
Norway & 1.95 & 1.66 & 0.09 & 3.89 \\
Sweden & 1.52 & 0.71 & 0.16 & 3.25 \\
United Kingdom & 1.41 & 0.33 & 0.24 & 2.21 \\
Belgium & 1.38 & 2.55 & -0.64 & 4.88 \\
Finland & 1.11 & 0.46 & 0.01 & 2.43 \\
Canada & 1.10 & 0.29 & 0.18 & 1.93
\end{tabular}

bottom ten

\begin{tabular}{lrrrr}
\hline Brazil & 0.01 & 0.00 & 0.00 & 0.02 \\
Romania & 0.01 & 0.00 & -0.00 & 0.02 \\
Indonesia & 0.00 & 0.00 & -0.00 & 0.02 \\
Ukraine & 0.00 & 0.00 & -0.00 & 0.02 \\
Russian Federation & 0.00 & 0.00 & 0.00 & 0.01 \\
Philippines & 0.00 & 0.00 & 0.00 & 0.01 \\
Pakistan & 0.00 & 0.00 & -0.00 & 0.01 \\
Venezuela & 0.00 & 0.00 & -0.00 & 0.01 \\
India & 0.00 & 0.00 & -0.00 & 0.00 \\
Turkey & 0.00 & 0.00 & -0.00 & 0.00
\end{tabular}


Table 3: Retained earnings on liabilities (top ten and bottom ten countries) (\%GDP)

Mean Variance Min Max

\begin{tabular}{lrrrr}
\multicolumn{1}{c}{ top ten } & \multicolumn{1}{c}{} \\
\hline Ireland & 10.32 & 75.90 & -2.04 & 23.64 \\
Hong Kong & 4.49 & 5.90 & 0.68 & 7.49 \\
Switzerland & 2.43 & 1.83 & -0.62 & 4.93 \\
Netherlands & 2.14 & 4.18 & 0.19 & 7.34 \\
Russian Federation & 1.59 & 0.50 & 0.59 & 2.44 \\
Finland & 1.08 & 1.06 & -0.53 & 2.83 \\
United Kingdom & 0.94 & 0.77 & -0.47 & 2.30 \\
Sweden & 0.90 & 0.27 & -0.30 & 1.72 \\
Korea & 0.85 & 0.07 & 0.46 & 1.25 \\
Denmark & 0.78 & 0.10 & 0.28 & 1.44
\end{tabular}

bottom ten

\begin{tabular}{lrrrr}
\hline Pakistan & 0.11 & 0.00 & 0.06 & 0.18 \\
Romania & 0.10 & 0.01 & 0.00 & 0.36 \\
Malaysia & 0.08 & 0.05 & 0.00 & 0.57 \\
Argentina & 0.07 & 0.01 & 0.00 & 0.24 \\
Venezuela & 0.06 & 0.00 & 0.00 & 0.19 \\
Czech Republic & 0.05 & 0.01 & -0.07 & 0.19 \\
Slovenia & 0.05 & 0.00 & -0.02 & 0.13 \\
Norway & 0.03 & 0.03 & -0.29 & 0.53 \\
Saudi Arabia & 0.02 & 0.00 & 0.02 & 0.02 \\
Turkey & 0.00 & 0.00 & 0.00 & 0.03
\end{tabular}


Table 4: Retained earnings correction (top ten and bottom ten countries) (\%GDP)

$$
\text { Mean Variance Min Max }
$$

top ten

\begin{tabular}{lrrrr}
\hline Norway & 1.92 & 1.65 & 0.09 & 3.97 \\
Belgium & 1.09 & 2.13 & -0.83 & 4.14 \\
Sweden & 0.62 & 0.43 & -1.20 & 1.53 \\
Chile & 0.60 & 0.24 & -0.51 & 1.13 \\
Canada & 0.57 & 0.46 & -0.17 & 1.83 \\
United Kingdom & 0.47 & 0.35 & -0.43 & 1.80 \\
Italy & 0.46 & 0.56 & -0.99 & 1.77 \\
Australia & 0.38 & 0.11 & -0.26 & 0.84 \\
Malaysia & 0.38 & 0.10 & -0.31 & 0.61 \\
Saudi Arabia & 0.38 & 0.00 & 0.34 & 0.42
\end{tabular}

bottom ten

\begin{tabular}{lrrrr}
\hline Ukraine & -0.26 & 0.32 & -1.53 & 0.02 \\
Japan & -0.29 & 0.14 & -0.94 & 0.46 \\
Indonesia & -0.30 & 0.06 & -0.62 & 0.22 \\
Brazil & -0.33 & 0.09 & -0.95 & 0.05 \\
Hungary & -0.35 & 0.21 & -1.43 & 0.08 \\
Philippines & -0.38 & 0.06 & -0.76 & 0.01 \\
Korea & -0.67 & 0.08 & -1.18 & -0.38 \\
Russian Federation & -1.59 & 0.50 & -2.44 & -0.58 \\
Hong Kong & -1.78 & 5.46 & -5.60 & 2.18 \\
Ireland & -2.84 & 106.64 & -21.75 & 12.46
\end{tabular}

Source: Own calculations 
Figure 6: Retained earnings correction variation over time across countries

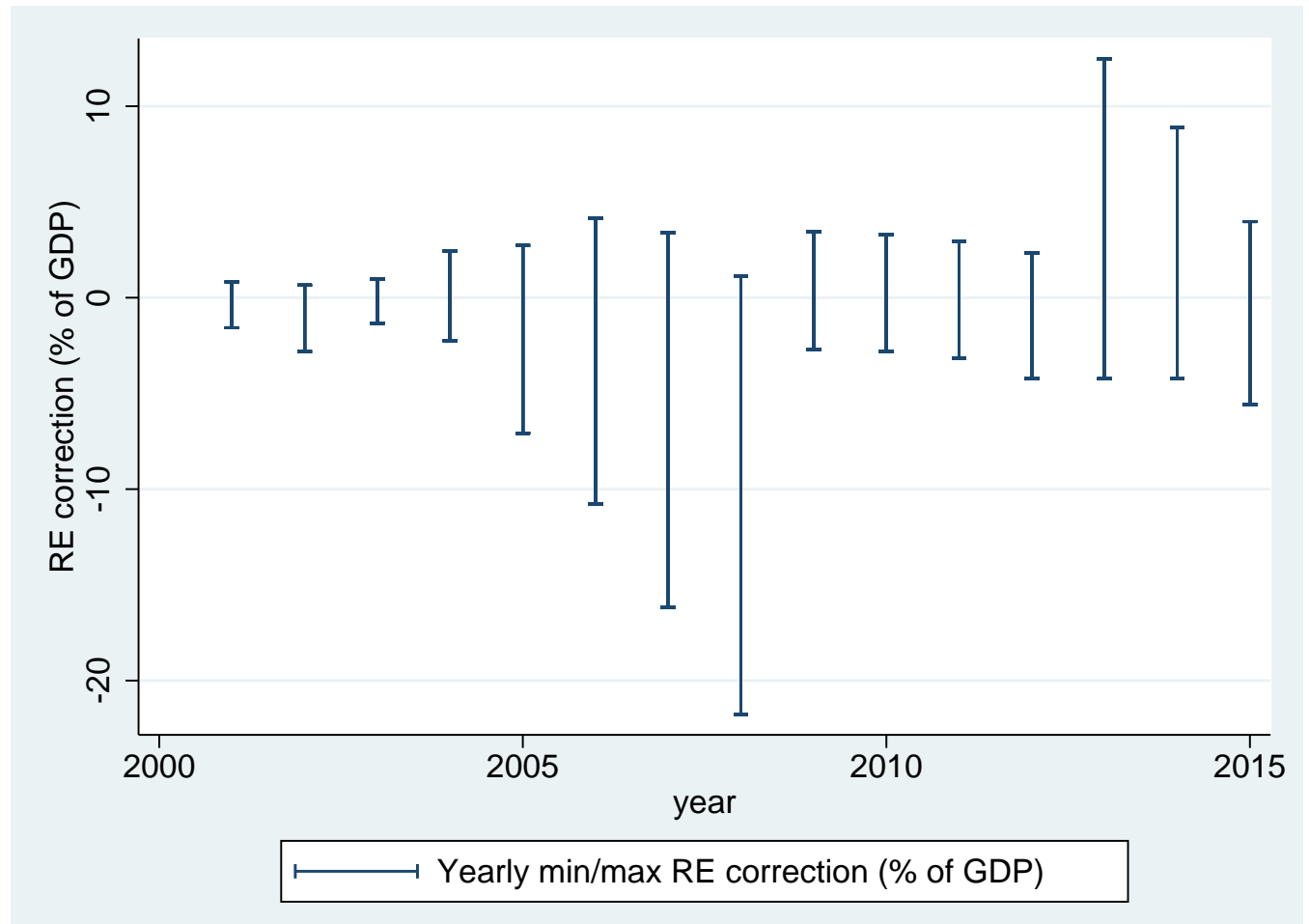

Source: Own calculations 


\section{Retained earnings and the global financial cri- sis}

This section re-examines the analysis of Lane and Milesi-Ferretti (2012) through the prism of official current accounts and corrected current accounts with RE. Lane and Milesi-Ferretti (2012) show for a panel of 65 countries that large adjustments in current account imbalances followed the GFC. They argue that countries whose pre-crisis current account balances were in excess of what can be explained by standard economic fundamentals have experienced the largest contractions in their external balance. They further claim that the adjustment process, especially for deficit countries, can be explained by adjustments in the trade balance tied to specific exchange-rate regimes. Our analysis for current accounts shows that the results of Lane and Milesi-Ferretti (2012) hold, even using the corrected current accounts with RE. Our empirical findings, however, point to an alternative interpretation that stresses the importance of financial linkages in addition to trade linkages 22 We argue that countries with large net imbalances of equity assets experienced an unusually large current account correction during the post-crisis period. This is explained by the fact that corporate profits were large and stable before the GFC and only partly reflected in dividends. Conversely, RE were large during the pre-crisis period and so were RE corrections, implying substantial downward corrections in the current account balance for countries with large negative net equity investment. However, corporate profits declined sharply as the crisis unfolded. This means that our RE correction is exceptionally small in the crisis period, and the corrected current accounts with RE lie close to the official current accounts. The large post-crisis adjustment of the official current account of financial centers stems from the overstatement of the official current account for the pre-crisis period. These same countries then experienced a large jump in their official current account surpluses in the post-crisis period.

The analysis by Lane and Milesi-Ferretti (2012) is a two-stage procedure. The first stage backs out the residuals from the macroeconomic balance (MB) model

\footnotetext{
${ }^{22}$ Analysis in the Appendix reveals that exchange-rate regimes defined by the peg dummy in Lane and Milesi-Ferretti (2012) did not matter. This result may be explained by the smaller country coverage in our sample, especially for emerging markets.
} 
by Lee et al. (2008), while the second stage regresses the change in the current account on the residuals. Lane and Milesi-Ferretti (2012) label the residuals from the MB model, GAP = current account - fitted values for the four-year average 2005-2008. The MB model is a standard reference for many empirical studies that analyze the behavior of new variables explaining the current account in the medium term (defined as a four-year average); see Beusch et al. (2017), Chinn and Ito (2008), and Chinn and Prasad (2003). The MB model includes the following fundamental variables: fiscal balance, growth differential, dependency ratio, aging, relative GDP per capita, lagged net foreign assets, and a series of dummy variables to capture country-specific factors (i.e., crisis dummy, financial-center dummy, Asian crisis dummy, oil balance dummy, and a separate Norway oil dummy). See Lee et al. (2008) for definitions, sources, and motivations of the variables.

Table 5 presents MB model estimates for the official current account data and corrected current accounts with RE for 44 countries. The estimation period is 2001-2008, and instead of four-year averages, an annual frequency is used ${ }^{23}$ Column 1 replicates the pooled estimate from Lee et al. (2008) with official current account data. This OLS regression includes lagged net foreign assets as a ratio of GDP rather than lagged current account balances. ${ }^{24}$ Column 2 uses the corrected current accounts with RE. The coefficient estimates are nearly identical for the two models, suggesting that the RE correction does not influence estimates for the medium-term models of the current account.

The second stage of Lane and Milesi-Ferretti (2012) regresses the differences between the current account of 44 countries in 2011, and its four-year average during 2005-2008, on the GAP. The baseline regression of Lane and Milesi-Ferretti (2012) takes the following form:

$$
\Delta C A_{i, 0508-11}=\alpha+\beta G A P_{i, 0508}+\gamma N F A_{i, 0407}+\epsilon_{i}
$$

where $\Delta C A_{i, 0508-11}$ is the difference between the current account of country $i$ in 2011 and its four-year average from 2005 to 2008 and $G A P_{i, 0508}$ is the average GAP

\footnotetext{
${ }^{23}$ Differences in the number of countries and time period do not allow us to derive estimates that replicate those of Lane and Milesi-Ferretti (2012).

${ }^{24}$ See also column 1 in Table 1 in Lee et al. (2008).
} 
from 2005 to 2008 for country $i$. Similarly, $N F A_{i, 0407}$ is the average ratio of NFA to GDP for country $i$ from 2004 to 2007 . The residual is denoted by $\epsilon$. The GAP's coefficient, $\beta$, is interpreted as the adjustment coefficient for global imbalances. To reconstruct the Lane and Milesi-Ferretti (2012) exercise, the in-sample (four-year average) GAPs from the annual residuals in Table 5 are used for the years 2005 to 2008.

Table 6 presents the second-stage estimates for the adjustment coefficient. Column 1 presents estimates using the official current account data and Column 2 the corrected current account data with RE. The adjustment coefficient is -0.42 for the specification with the official current account data and -0.64 for the corrected current account data. Both coefficients are statistically significant. Lane and Milesi-Ferretti (2012) obtain an estimate of -0.57 for a larger sample. The adjustment coefficient of -0.57 says that roughly half of an excess deficit in the current account not explained by fundamentals is corrected with an improved current account balance in four years.

Next, to determine whether adjustment in the current account balance between the average period 2005-2008 and 2011 is greater for countries with large equity investments, the baseline regression is extended to capture the interaction term between the GAP and financial centers:

$$
\Delta C A_{i, 0508-11}=\alpha+\lambda F I N_{i}+\beta G A P_{i, 0508}+\gamma N F A_{i, 0407}+\delta F I N_{i} G A P_{i, 0508}+\epsilon_{i},
$$

where the dummy variable, $F I N_{i}$, is +1 if a criterion capturing equity investment for country $i$ is fulfilled and zero otherwise. Three criteria regarding a country's size and imbalance of equity investment are considered. $S I Z E_{i}$ is a dummy set to +1 for (equity assets + equity liabilities)/GDP $>70 \%$ in 2008 and to 0 otherwise $25 I M B A L A N C E_{i}$ is a dummy set to +1 when the absolute value (equity assets - equity liabilities)/GDP $>20 \%$ in 2008, 0 otherwise ${ }^{26}$ FinCenter $_{i}$ is the

\footnotetext{
${ }^{25}$ The countries that fulfill this criteria in 2008 are Ireland, Hong Kong, the Netherlands, Norway, Sweden, Switzerland, and the United Kingdom.

${ }^{26}$ The countries that fulfill this criteria in 2008 are Chile, Denmark, Finland, India, Ireland, Hong Kong, Norway, and Switzerland.
} 
Table 5: Medium-term current account models

\begin{tabular}{|c|c|c|}
\hline & $\begin{array}{c}(1) \\
\text { Official }\end{array}$ & $\begin{array}{c}(2) \\
\text { Corrected }\end{array}$ \\
\hline Fiscal Balance (in deviation of trading partner average) & $\begin{array}{l}0.322^{* *} \\
(0.105)\end{array}$ & $\begin{array}{l}0.322^{* *} \\
(0.104)\end{array}$ \\
\hline Old age dependency ratio (in deviation of trading partner average) & $\begin{array}{c}0.254^{*} \\
(0.112)\end{array}$ & $\begin{array}{c}0.351^{* *} \\
(0.119)\end{array}$ \\
\hline Population growth (in deviation of trading partner average) & $\begin{array}{c}1.471 \\
(1.039)\end{array}$ & $\begin{array}{c}1.556 \\
(1.140)\end{array}$ \\
\hline Lagged NFA as a ratio of GDP (Source: Lane and Milesi-Ferretti 2007) & $\begin{array}{c}0.0281^{*} \\
(0.013)\end{array}$ & $\begin{array}{c}0.0283^{*} \\
(0.012)\end{array}$ \\
\hline Oil balance only for Norway & $\begin{array}{c}0.470^{* * *} \\
(0.097)\end{array}$ & $\begin{array}{c}0.575^{* * *} \\
(0.118)\end{array}$ \\
\hline Oil balance except for Norway & $\begin{array}{c}0.249^{* * *} \\
(0.065)\end{array}$ & $\begin{array}{c}0.264^{* * *} \\
(0.067)\end{array}$ \\
\hline Output growth for emerging countries & $\begin{array}{l}-0.151 \\
(0.133)\end{array}$ & $\begin{array}{l}-0.200 \\
(0.147)\end{array}$ \\
\hline Relative income (ratio of PC PPP GDP to the US level, 2000 USD) & $\begin{array}{c}-0.0389 \\
(0.023)\end{array}$ & $\begin{array}{c}-0.0563 \\
(0.028)\end{array}$ \\
\hline Banking crisis dummy (Source: Laeven and Valencia 2012) & $\begin{array}{c}-0.00416 \\
(0.010)\end{array}$ & $\begin{array}{c}-0.0166 \\
(0.015)\end{array}$ \\
\hline Dummy for Asian Crisis from 1997 (1=Emerging Asian Country, 0=Other) & $\begin{array}{c}0.0408^{*} \\
(0.016)\end{array}$ & $\begin{array}{c}0.0451^{*} \\
(0.017)\end{array}$ \\
\hline Dummy for financial center (BEL, CHE, HKG, NLD) & $\begin{array}{c}0.0452^{*} \\
(0.022)\end{array}$ & $\begin{array}{c}0.0557^{* *} \\
(0.020)\end{array}$ \\
\hline Dummy for euro introduction on Germany, Portugal, Spain, Greece & $\begin{array}{c}0.0580^{\text {*** }} \\
(0.012)\end{array}$ & $\begin{array}{c}0.0611^{* * *} \\
(0.012)\end{array}$ \\
\hline Dummy for effect of aging on Germany, Switzerland, Italy, and Japan & $\begin{array}{c}0.00614 \\
(0.018)\end{array}$ & $\begin{array}{c}0.00605 \\
(0.018)\end{array}$ \\
\hline Constant & $\begin{array}{l}0.0279 \\
(0.016) \\
\end{array}$ & $\begin{array}{c}0.0372^{*} \\
(0.017)\end{array}$ \\
\hline $\begin{array}{l}\text { Observations } \\
\text { Adjusted } R^{2}\end{array}$ & $\begin{array}{c}345 \\
0.687\end{array}$ & $\begin{array}{c}345 \\
0.656\end{array}$ \\
\hline
\end{tabular}

Standard errors in parentheses

${ }^{*} p<0.05,{ }^{* *} p<0.01,{ }^{* * *} p<0.001$ 
interaction between $S I Z E_{i}$ and $I M B A L A N C E_{i} \cdot{ }^{27}$ A negative coefficient of the interaction term, $\delta$, suggests that countries with a large equity investment balance experienced greater current account adjustment than the global average, captured by $\beta$.

To understand how RE contributed to the adjustment process, a dummy for financial centers is integrated into the baseline regressions of Columns 1 and 2, where financial centers are defined as countries with large equity positions. Columns 3 and 4 of Table 6 report the regression results including this dummy and the interaction terms with the GAP. Column 3 shows that the introduction of the $S I Z E_{i}$ dummy has no large constant or slope effect for global adjustment for the official current account specification. The global adjustment coefficient is -0.46 and the coefficients for $S I Z E_{i}$ and the interaction term are 0.03 and 0.12 , however the interaction term is statistically insignificant. The same regression in Column 4 for the specification with the corrected current accounts shows that the global adjustment coefficient declines sharply to -0.36 and the coefficients for $S I Z E_{i}$ and the interaction term are 0.05 and -0.59. The estimated coefficient of -0.59 for the interaction term indicates that countries with a high level of equity openness, measured by the size of their asset and liability positions, adjusted more strongly.

Next, regressions in Columns 5 and 6 repeat the exercise based on a different definition of financial center, namely that of large net equity imbalances. This criterion for the $I M B A L A N C E_{i}$ dummy has no statistically significant effect for the specification using official current account data shown in Column 5. The global adjustment coefficient is -0.40 and remains statistically significant. Instead, for the specification with the corrected current account data with RE, the coefficient for the interaction term is -0.78 and statistically significant. Moreover, the global adjustment coefficient falls to -0.35 and is statistically significant. This result suggests that countries with large equity imbalances underwent a current account adjustment that was more than twice as large as the global average. In other

\footnotetext{
${ }^{27}$ The thresholds for $S I Z E_{i}$ and $I M B A L A N C E_{i}$ were intentionally set to allow as many countries as possible into the set of financial center countries. These however were not determinant for the outcome of the interaction between $S I Z E_{i}$ and $I M B A L A N C E_{i}$.
} 


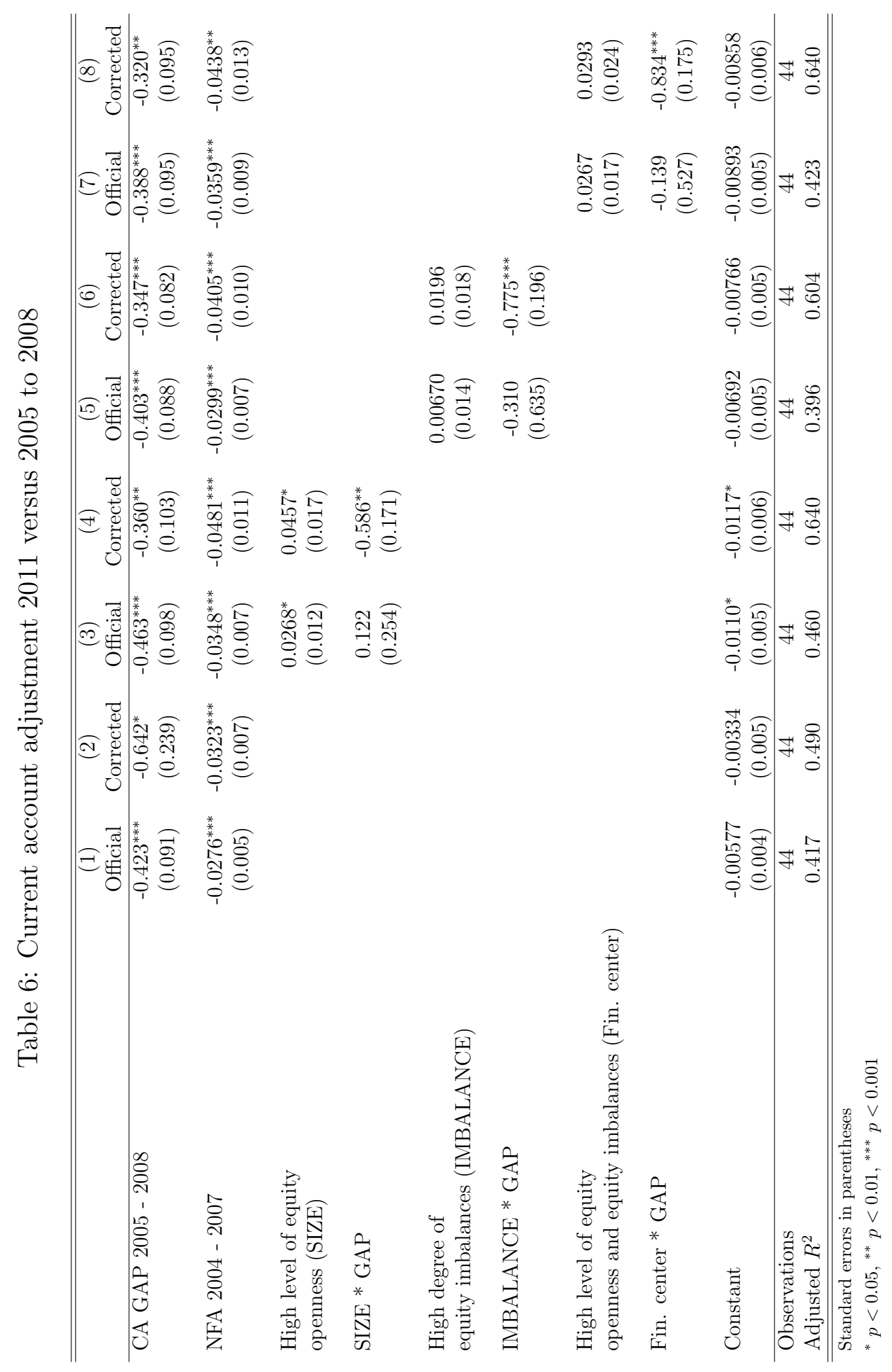


words, part of the adjustment in global imbalances was financial, and especially in countries with large equity imbalances.

The last two regressions in Columns 7 and 8 consider the effect of the financial equity centers separately, i.e., the interaction of the $S I Z E_{i}$ and $I M B A L A N C E_{i}$ dummies. Only Ireland, Hong Kong, Norway, and Switzerland fulfill the joint criteria in 2008. The regressions again show that for the specification with the official current account data, there is no large deviation from the previous regressions shown in Columns 1, 3, and 5. The global adjustment coefficient is -0.39 and statistically significant. The coefficients for the financial equity center dummy and the interaction term are small and statistically insignificant. The picture changes considerably for the specification with corrected current account data with RE. The coefficient for global adjustment falls further to -0.32 and is statistically significant, while the coefficient of the interaction term remains large at -0.83 and is statistically significant 28

We interpret the results from Table 6 as suggestive evidence highlighting the importance of financial linkages through RE for current account adjustment. In other words, the official current account balances of the financial center countries were overstated particularly before the GFC. After the GFC, RE were small and so were the differences between the official and corrected current accounts with RE. This means that the extent of current account adjustment in financial center countries was understated based on official current account data.

\section{Conclusion}

This paper offers a strategy to calculate RE for foreign equity investment and analyzes the effect of RE on current account adjustment in a global context. In the case of equity investment, BoP accounting only allots dividend payments to foreign shareholders and not RE, as is assumed to be the case for foreign direct investment. We find that allocating RE to foreign shareholders can alter the dynamics of current accounts. Although this correction primarily affects the so-called equity financial centers, the sizes of income from equity investment are nontrivial, and

\footnotetext{
${ }^{28}$ Robustness tests for this empirical exercise can be found in the Appendix.
} 
tend to vary strongly for several countries over time. These findings raise new questions about properly measuring the effects of income and the appropriate policy towards external balance adjustment. 


\section{References}

Beusch, E., Döbeli, B., Fischer, A. M., Yesin, P., 2017. Merchanting and current accountbalances. WorldEconomy40 (1), 140- 167.

https:// doi.org/ 10.1111/ twec.12355

Blanchard, O., Acalin, J ., 2016. What does measured FDI actually measure? Peterson Institutefor International Economics, Policy Brief 16- 17.

Caballero, R. J ., Farhi, E., Gourinchas, P. O., 2016. Safe asset scarcity and aggregatedemand.American EconomicReview 106(5), 513-518. https:/ / doi.org/ 10.1257/ aer.p20161108

Chinn, M., Prasad, E. S., 2003. Medium-term determinants of current accounts in industrial and developing countries: An empirical exploration. J ournal of International Economics 59, 47- 76. https:// doi.org/ 10.1016/ s00221996(02)00089-2

Chinn, M. D., Ito, H., 2006. What mattersfor financial development? capital controls, institutions, and interactions.J ournal of Development Economics 81(1), 163- 192. https:/ / doi.org/ 10.1016/j.jdeveco.2005.05.010

Chinn, M. D., Ito, H., 2008. Global current account imbalances: American fiscal policy versus East Asian savings. Review of International Economics 16 (3), 479-498. https:// doi.org/ 10.1111/j.1467-9396.2008.00741.x

Curcuru, S. E., Dvorak, T., Warnock, F. E., 2010. Decomposing the US external returns differential. J ournal of International Economics 80 (1), 22- 32. https:/ / doi.org/ 10.1016/j.jinteco.2009.06.005

Curcuru, S. E., Thomas, C. P., Warnock, F. E., 2013. On international returns. J ournal of International Money and Finance 36, 1- 25. https:/ / doi.org/ 10.1016/j.jimonfin.2013.02.002

Devereux, M. B., Sutherland, A., 2010. Valuation effects and the dynamics of net external assets. J ournal of International Economics 80 (1), 129- 143. https:/ / doi.org/ 10.1016/j.jinteco.2009.06.001 
Eggelte, J ., Hillebrand, R., Kooiman, T., Schotten, G., 2014. Getting to the bottom of the Dutch savings surplus. Occasional Studies, De Nederlandsche Bank $12-6$.

Fitzgerald, J ., 2013. The effect of re-domiciled plcs on Irish output measures and the balance of payments. ESRI QECResearch Note (2013/1/2).

Gourinchas, P. O., Rey, H., 2007. International financial adjustment. J ournal of Political Economy 115 (4), 665- 703. https:// doi.org/ 10.1086/521966

Gourinchas, P. O., Rey, H., Truempler, K., 2012. The financial crisis and the geography of wealth transfers. J ournal of International Economics 88, 266283. https:// doi.org/ 10.1016/j.jinteco.2012.05.008

International Monetary Fund, 2000. Offshore financial centers. IMF Background Paper, Washington D.C.

International Monetary Fund, 2009. Balance of Payments and International InvestmentPosition Manual. Washington, D.C., 6th Edition.

International Monetary Fund, 2016. 2016 External Sector Report - Individual Economy Assessments. Washington, D.C., 53-54.

Laeven, L., Valencia, F., 2012. Systemic banking crises database; an update. IMF WorkingPapers (12/ 163), International Monetary Fund. https:// doi.org/ 10.5089/9781475505054.001

Lane, P., 2014. International financial flows and the Irish crisis. CESifo Forum 15 (2), 14- 19.

Lane, P., Milesi-Ferretti, G. M., 2007. The external wealth of nations mark II: Revised and extended estimates of foreign assets and liabilities, 1970-2004.J ournal of International Economics 73 (2), 223- 250. https:/ / doi.org/ 10.1016/j.jinteco.2007.02.003

Lane, P., Milesi-Ferretti, G. M., 2012. External adjustment and the global crisis. J ournal of International Economics 88, 252- 265. https:// doi.org/ 10.1016/j.jinteco.2011.12.013 
Lee, J ., Milesi-Ferretti, G. M., Ostry, J., Prati, A., Ricci, L. A., 2008. Exchange rate assessments: CGER methodologies. IMF Occasional Paper 261, International Monetary Fund. https:/ / doi.org/ 10.5089/ 9781589066380.084

McCauley, R. N., McGuire, P., 2009. Dollarappreciationin 2008: safehaven, carry trades, dollar shortage and overhedging. BIS Quarterly Review (December), 8593.

McGuire, P., Goetz, P., 2009. The US dollar shortage in global banking. BIS Quarterly Review (March), 47-63.

Mian, O., Sauré, P., 2018. Cross-country inflation differentials as a source of Switzerland's current account surplus. Swiss National Bank mimeo.

Obstfeld, M., 2012. Does the current account still matter? American Economic Review 102 (3), 1- 23.

Rose, A., Spiegel, M., 2007. Offshore financial centers: Parasites or symbiots. Economic J ournal 117 (523), 1310- 1335. https:/ / doi.org/ 10.1111/j.14680297.2007.02084.x

Swiss National Bank, 2006. Swiss balance of payments 2006. Zurich: Swiss National Bank, 26- 27. 


\section{Appendix}

\section{A Data}

\section{A.1 Portfolio equity investment stocks}

\section{A.1.1 Bilateral positions}

The RE calculation strategy presented in section 3 of the paper is for portfolio equity investments without investment fund shares, because RE on investment fund shares are already taken into account in the compilation of the official current account statistics in the BPM6 methodology.

The IMF's CPIS data set offers extensive coverage and the necessary country breakdown of portfolio equity investments to calculate the RE correction. A drawback, however, is that it includes investment fund shares. Even though most countries invest only a small amount in investment fund shares, it is important to note their presence in the CPIS. Luxembourg (not in our sample of 44 countries) and Ireland (in our sample) are exceptions, because it is known that these two countries have a high level of investment fund shares.

For the RE calculation, however, the CPIS data only enter in the RE correction as country weights, i.e., they capture the relative importance of one country's portfolio equity investment in another country with respect to the latter's total foreign portfolio equity liabilities. CPIS data are needed for the estimation, because they provide stock data on a bilateral level and for the relevant time horizon, even if investment fund shares are included. Unfortunately, portfolio equity investment stocks that exclude investment fund shares only exist at an aggregate level. We assume that a country's country breakdown of equity only investment is identical to its equity investment including investment funds. In other words, the CPIS shares would remain unchanged if we could subtract investment fund shares. Because for most countries in our sample investment funds are relatively unimportant for portfolio investment, our assumption does not distort the estimation.

One-year lagged country weights of cross-border positions are used in the calcu- 
lation of the retained earnings (RE) correction. That is because dividend and $\mathrm{RE}$ flows in a given period depend on previous period's investment positions. An exception in the estimation is the year 2001. Here, the contemporaneous weights of 2001 are considered, because the CPIS database begins in the same year.

\section{A.1.2 Aggregate stocks}

However, to set the values of the SIZE and IMBALANCE dummy variables as described in the paper, CPIS is no longer a good source. To calculate the financial openness characteristics, only the aggregate cross-border positions in portfolio equity investments are of interest. Data excluding investment fund shares are available for this level and their source is the IMF's BOPS International Investment Position (IIP) data.

With the IMF BOPS data, we calculate the share of investment funds in total portfolio equity investments for each country over time. Table 1 lists the share of portfolio equity investment only in total portfolio equity investment. Using this information, we scale the CPIS data to have estimates of portfolio equity investments excluding investment fund shares for each country in each year of the sample. The calculation is based on the following methodology:

a) If no IMF BOPS investment fund data are available, we assume investment funds are negligible and thus CPIS values already represent portfolio equity investments excluding investment fund shares.

b) If investment fund shares can be calculated for all years for one country, then we use each share to scale down CPIS values (once for assets, once for liabilities).

c) If investment fund shares are available starting at a later point in time than 2001 for one country, then we assume the earliest value available represents the share for all previous years. Then we scale down CPIS assets and liabilities, as for item (b).

Thus if criterion (a) or (c) holds, then the RE correction is likely to be inaccurate. For instance, for Ireland, there is no information on the importance of investment fund shares in portfolio equity liabilities. It is not realistic to assume that these investment fund positions are negligible. Nevertheless, we can confidently classify 
Ireland as a financial equity center, because the sheer size of Ireland's asset position in equity is sufficient to set both the SIZE and IMBALANCE dummies equal to 1. Here is the intuition: If Ireland had no equity liabilities, then the sum of assets and liabilities would be $237 \%$ GDP in 2008, clearly above the $80 \%$ GDP threshold, and the net equity positon would be also $237 \%$ GDP, again above the $20 \%$ GDP imbalance threshold. On the other hand, if Ireland had equity liabilities of, say, $44 \%$ GDP (which is equal to the market capitalization), its assets plus liabilities in portfolio equity would be $281 \%$ GDP, again well above the size threshold. And the net equity position would be $193 \%$ GDP, once again clearly above the imbalance threshold. 
Table A1: Shares of portfolio equity only investment (excluding investment fund shares) in total portfolio equity investments as of 2015 (in \%)

\begin{tabular}{lcc}
\hline Country & Assets & Liabilities \\
\hline Austria & 38.23 & 61.16 \\
Romania & 31.59 & 65.97 \\
Belgium & 31.24 & 73.74 \\
France & 64.40 & 77.02 \\
United States & 87.30 & 78.97 \\
Germany & 43.82 & 79.88 \\
Finland & 33.08 & 81.42 \\
Norway & 96.18 & 84.12 \\
Switzerland & 50.50 & 91.14 \\
Hungary & 24.91 & 92.85 \\
Sweden & 63.89 & 94.05 \\
Denmark & 81.96 & 95.39 \\
Greece & 6.52 & 96.20 \\
Czech Republic & 39.71 & 96.55 \\
Portugal & 44.56 & 96.63 \\
Slovenia & 60.74 & 97.35 \\
Netherlands & 65.73 & 97.53 \\
Spain & 31.51 & 98.67 \\
Japan & 44.30 & 99.18 \\
Italy & 13.21 & 99.52 \\
Russian Federation & 79.63 & 99.65 \\
United Kingdom & 80.06 & 99.82 \\
Ireland & 74.87 & \\
\hline
\end{tabular}

Source: IMF BOPS

Note: Empty cells represent missing values. Sample countries are missing if no IMF BOPS data are available in 2015. 


\section{A.2 Dividend payout ratio}

\section{A.2.1 Definitions}

1. IS_TOT_CASH_COM_DVD: Dividends paid to common shareholders from company profits. It includes cash as well as special cash dividends for all classes of common shareholders. It excludes the return of capital (except for Switzerland and Taiwan, which include recurring returns of capital) and in-specie dividends.

2. INC_BEF_XO_LESS_MIN_INT_PREF_DVD: Returns income before extraordinary items and discontinued operation but after minority interest, preferred dividend, and other adjustments. Calculated as: pretax income - income tax - after tax (income) loss from affiliates - minority interest - preferred dividends - other adjustment.

3. DVD_PAYOUT_RATIO: Fraction of net income a firm pays to its shareholders in dividends, in percentage. Calculated as: total cash common dividend *100 / income before extraordinary items less minority and preferred dividends, where: total cash common dividend is IS_TOT_CASH_COM_DVD; income before extraordinary items less minority and preferred dividends is: INC_BEF_XO_LESS_MIN_INT_PREF_DVD. 


\section{A.2.2 List of countries' leading market indices for which Bloomberg dividend payout ratio is available}

Table A2: Leading stock market indices

\begin{tabular}{|c|c|c|c|}
\hline Country & Leading stock market index & Country & Leading stock market index \\
\hline Argentina & MERVAL & Spain & IBEX \\
\hline Australia & S\&P/ASX 200 & Sweden & OMX Stockholm 30 \\
\hline Austria & ATX Index & Switzerland & SMI \\
\hline Belgium & BEL 20 & Turkey & ISE 30 \\
\hline Brazil & Ibovespa & Ukraine & PFTS \\
\hline Canada & $\mathrm{S} \& \mathrm{P} / \mathrm{TSX}$ & United Kingdom & FTSE100 Index \\
\hline Chile & IPSA & United States & Dow Jones \\
\hline Colombia & IGBC & Venezuela & IBVC \\
\hline Czech Republic & PX Index & & \\
\hline Denmark & OMX Copenhagen 20 & & \\
\hline Finland & OMXH25 & & \\
\hline France & CAC 40 & & \\
\hline Germany & DAX & & \\
\hline Greece & Athex & & \\
\hline Hong Kong & HSI & & \\
\hline Hungary & BUX & & \\
\hline India & CNX Nifty & & \\
\hline Indonesia & JCI & & \\
\hline Ireland & ISEQ & & \\
\hline Israel & TA-25 & & \\
\hline Italy & IT30 Index & & \\
\hline Japan & Nikkei 225 & & \\
\hline Korea & Kospi 50 & & \\
\hline Malaysia & FBM KLCI & & \\
\hline Netherlands & AEX & & \\
\hline New Zealand & NZX 50 & & \\
\hline Norway & OBX & & \\
\hline Pakistan & KSE 100 & & \\
\hline Philippines & PSE Index & & \\
\hline Poland & WIG30 & & \\
\hline Portugal & PSI-20 & & \\
\hline Romania & BET & & \\
\hline Russian Federation & RTS & & \\
\hline Saudi Arabia & SASEIDX & & \\
\hline Slovenia & SBI Top / SBI 20 & & \\
\hline South Africa & FTSE/JSE & & \\
\hline
\end{tabular}

Source: Bloomberg 


\section{A.3 Dividends}

Whenever available, the dividends data are "dividends on portfolio equity investments excluding investment funds shares" for current account expenses. When these data are unavailable for a given country-year pair, then we use "dividends on portfolio equity investments and investment fund shares." Table A3 summarizes which data are used for each country-year pair.

When data on "dividends on portfolio equity only" are available, then the RE estimate is as accurate as possible for that year and country. However, when data on "dividends on portfolio equity and investment fund shares" are used, then the RE estimate may be over-estimated or under-estimated, depending on whether it is the $\mathrm{RE}$ expenses or $\mathrm{RE}$ receipts that are affected in the estimation. The error may be larger or smaller depending on the relative size of investment fund shares in portfolio investment. 
Table A3: Country-year data availabilities

\begin{tabular}{|c|c|c|}
\hline Country & $\begin{array}{l}\text { Dividends on equity } \\
\text { only }\end{array}$ & $\begin{array}{l}\text { Dividends on equity } \\
\text { and on investment } \\
\text { fund shares }\end{array}$ \\
\hline & \multicolumn{2}{|c|}{ Expenses } \\
\hline $\begin{array}{c}\text { Australia, Colombia, } \\
\text { France, Germany, Hungary, } \\
\text { New Zealand, Russian } \\
\text { Federation, Switzerland, } \\
\text { United Kingdom and } \\
\text { United States }\end{array}$ & $2001-2015$ & - \\
\hline Sweden & $2003-2015$ & 2001,2002 \\
\hline Netherlands and Poland & $2004-2015$ & $2001-2003$ \\
\hline Pakistan and Philippines & $2005-2015$ & $2001-2004$ \\
\hline $\begin{array}{c}\text { Argentina, Finland and } \\
\text { Austria (data starting only } \\
\text { in 2005) }\end{array}$ & $2006-2015$ & $2001-2005$ \\
\hline $\begin{array}{l}\text { Czech Republic, Italy and } \\
\text { Slovenia }\end{array}$ & $2008-2015$ & $2001-2007$ \\
\hline Greece & $2009-2015$ & $2001-2008$ \\
\hline Brazil & $2010-2015$ & $2001-2009$ \\
\hline $\begin{array}{l}\text { India and Belgium (data } \\
\text { starting only in 2002) }\end{array}$ & $2012-2015$ & $2001-2011$ \\
\hline $\begin{array}{c}\text { Denmark, Portugal and } \\
\text { Romania }\end{array}$ & $2013-2015$ & $2001-2012$ \\
\hline $\begin{array}{c}\text { Japan and Ireland (data } \\
\text { starting only in 2005) }\end{array}$ & 2014,2015 & $2001-2013$ \\
\hline Turkey & $\begin{array}{l}2001-2003,2005 \\
2007,2010,2011 \\
2013-2015\end{array}$ & $\begin{array}{l}2004,2006,2008 \\
2009,2012\end{array}$ \\
\hline Venezuela & $2005-2013$ & $\begin{array}{c}2001-2004,2014 \\
2015\end{array}$ \\
\hline $\begin{array}{l}\text { Canada, Chile, Hong Kong, } \\
\text { Indonesia, Israel, Korea, } \\
\text { Malaysia, Norway, South } \\
\text { Africa, Spain, Ukraine, and } \\
\text { Saudi Arabia (data starting } \\
\text { only in 2006) }\end{array}$ & - & $2001-2015$ \\
\hline
\end{tabular}

Source: IMF BOPS, SNB 


\section{A.4 Coverage}

\section{A.4.1 Portfolio equity investment}

Table A4: Sum of portfolio investment in equity in the sample / World's total portfolio investment in equity (in \%)

\begin{tabular}{lcc}
\hline Year & Assets & Liabilities \\
\hline 2001 & 90.42 & 81.91 \\
2002 & 89.33 & 78.70 \\
2003 & 88.25 & 79.19 \\
2004 & 87.87 & 78.07 \\
2005 & 87.35 & 78.09 \\
2006 & 86.98 & 76.65 \\
2007 & 85.90 & 73.78 \\
2008 & 85.29 & 71.85 \\
2009 & 85.65 & 72.70 \\
2010 & 86.18 & 72.24 \\
2011 & 86.65 & 70.55 \\
2012 & 86.73 & 69.99 \\
2013 & 86.60 & 71.71 \\
2014 & 86.71 & 69.09 \\
2015 & 82.87 & 69.32 \\
Time average & 86.85 & 74.26 \\
\hline
\end{tabular}

Source: IMF CPIS, own calculations 


\section{A.4.2 GDP}

Table A5: Sum of country GDPs in the sample / World GDP (in \%)

\begin{tabular}{lc}
\hline Year & Coverage \\
\hline 2000 & 87.86 \\
2001 & 87.31 \\
2002 & 87.04 \\
2003 & 87.34 \\
2004 & 87.05 \\
2005 & 86.16 \\
2006 & 85.04 \\
2007 & 83.93 \\
2008 & 82.21 \\
2009 & 81.33 \\
2010 & 79.86 \\
2011 & 78.49 \\
2012 & 77.01 \\
2013 & 75.78 \\
2014 & 74.98 \\
2015 & 73.63 \\
Time average & 82.19 \\
\hline
\end{tabular}

Source: World Bank WDI, own calculations 


\section{A.5 Missing values}

In the empirical exercise of the paper, there are missing values that have been replaced as follows:

a) Venezuela 2007 oil exports. This observation is replaced with its 2006 value.

b) The IMF doesn't provide 2004 current account values for Austria and Ireland (the IMF began to publish values for these countries in 2005). These two missing observations are replaced with their OECD values.

c) No data for portfolio equity assets and liabilities are available for Slovenia in 2008. The data are, however, available between 2010 and 2015. The sum of equity assets and liabilities is $8 \%$ of GDP and net equity assets are $2 \%$ of GDP. Therefore, we assume that the dummy variables of IMBALANCE and SIZE are both zero for Slovenia. 


\section{B Statistical properties of corrected current ac- counts with retained earnings}

To understand the influence of the RE correction on the current account, Tables B1 and B2 present the official figures and the RE-corrected figures. The mean of the RE correction does not strongly affect the current account rankings of the ten largest surplus and deficit countries. However, a notable feature is the variance in the financial equity centers. The variance of the corrected current accounts of the financial equity centers is higher than the official figures, except for Norway.

To understand the contrasting dynamics of the RE corrections and their effects on the current account, Figures B1 to B4 plot the official current account, the corrected current account (i.e., the official current account plus the RE correction), and the RE correction for the financial equity center countries Hong Kong, Ireland, Norway, and Switzerland. The figures highlight that the correction is time-varying and has a different profile for each country. Figure B1 shows the interesting case for Hong Kong. The correction has a strong negative trend. The correction declines steadily from $2 \%$ of GDP in 2004 to $-6 \%$ with respect to GDP in 2015 . As a consequence, the corrected current account is much smaller than is suggested by the official current account. This strong trend in the correction also influences a country's medium-term GNI.

Next, Figure B2 shows that the RE correction for Ireland is strongly negative until 2009 and then becomes positive, and even achieves 10\% of GDP in 2013. The Irish case is of particular interest because the corrected current account reveals a much higher degree of financial vulnerability than the official data on external accounts. This point has been previously noted by Lane 2014) and Fitzgerald (2013).

The Norwegian correction differs from the other financial equity centers in that its RE are positive with an increasing trend. As shown in Figure B3, this means that the corrected current account is much larger than the official current account. The positive earnings correction arises from the fact that Norway's sovereign wealth fund is large and invests heavily in foreign equity. The key point is that Norway is highly financially integrated because of its oil fund, and not due 
to its listings of international companies.

Figure B4 shows the RE correction for Switzerland. The RE correction is negative for the most recent years (i.e., between $-2 \%$ and $-1 \%$ of GDP). As a consequence, the corrected current account has been below the official figures since the financial crisis. However, the correction was positive before the financial crisis, suggesting a possible shift in preferences towards Swiss equity among international investors after the financial crisis.

It is unclear how the correction for the RE in the current account co-moves with capital flows defined by the (official) financial account. A simple exercise compares the gap between the corrected current account and the (official) financial account with the errors and omissions derived from the (official) current account minus the (official) financial account. Table B3 presents this information for all 44 countries. It shows that the mean gap between the corrected current account and the (official) financial account is smaller for 21 countries than the mean errors and omissions. The sum of the absolute values of the errors and omissions over all countries increases by $24.5 \%$ for the corrected current account. 
Table B1: Current account official (top ten and bottom ten countries) (\%GDP)

Mean Variance Min Max

top ten

\begin{tabular}{lrrrr}
\hline Norway & 12.79 & 5.51 & 8.04 & 16.19 \\
Switzerland & 10.36 & 11.71 & 2.37 & 14.79 \\
Malaysia & 10.28 & 23.45 & 3.06 & 16.86 \\
Hong Kong & 7.84 & 20.37 & 1.39 & 14.99 \\
Netherlands & 6.74 & 6.46 & 2.30 & 10.80 \\
Russian Federation & 6.26 & 8.93 & 1.46 & 11.05 \\
Sweden & 6.07 & 1.40 & 4.62 & 8.21 \\
Venezuela & 6.02 & 43.88 & -4.66 & 17.49 \\
Germany & 5.19 & 6.11 & -0.36 & 8.91 \\
Denmark & 4.72 & 6.29 & 1.52 & 8.88
\end{tabular}

bottom ten

\begin{tabular}{lrrrr}
\hline United Kingdom & -3.51 & 1.65 & -5.54 & -1.94 \\
Poland & -3.73 & 3.33 & -6.71 & -0.56 \\
United States & -3.74 & 1.72 & -5.82 & -2.09 \\
New Zealand & -3.94 & 4.68 & -7.70 & -0.78 \\
Spain & -4.07 & 14.10 & -9.68 & 1.52 \\
Turkey & -4.12 & 7.13 & -8.94 & 1.88 \\
Australia & -4.72 & 2.54 & -7.52 & -2.11 \\
Romania & -6.03 & 15.63 & -13.95 & -0.69 \\
Portugal & -6.91 & 21.14 & -12.19 & 1.59 \\
Greece & -7.27 & 19.61 & -14.48 & -0.23
\end{tabular}

Source: IMF BOPS, SNB, own calculations 
Table B2: Current account corrected (top ten and bottom ten countries) (\%GDP)

Mean Variance Min Max

top ten

\begin{tabular}{lrrrr}
\hline Norway & 14.71 & 3.36 & 12.02 & 18.05 \\
Switzerland & 10.47 & 21.63 & -0.50 & 18.15 \\
Malaysia & 7.92 & 20.28 & 3.51 & 15.41 \\
Netherlands & 7.14 & 12.14 & 0.97 & 12.50 \\
Sweden & 6.68 & 1.49 & 5.17 & 9.74 \\
Venezuela & 6.28 & 45.76 & -4.66 & 17.47 \\
Hong Kong & 6.06 & 40.70 & -2.85 & 14.07 \\
Germany & 5.24 & 5.63 & -0.46 & 8.56 \\
Denmark & 5.00 & 7.79 & 1.59 & 9.69 \\
Russian Federation & 4.37 & 6.93 & 0.75 & 8.98 \\
& & & & \\
bottom ten & & & & \\
\hline United States & -3.55 & 1.13 & -5.37 & -2.22 \\
Colombia & -3.59 & 2.04 & -6.30 & -2.00 \\
New Zealand & -3.84 & 4.75 & -7.82 & -1.68 \\
Poland & -3.88 & 3.68 & -6.86 & -0.56 \\
Spain & -4.27 & 14.22 & -9.78 & 1.54 \\
Australia & -4.33 & 3.16 & -7.78 & -2.01 \\
Turkey & -5.09 & 3.16 & -8.94 & -1.76 \\
Romania & -6.00 & 22.47 & -14.02 & -0.72 \\
Portugal & -6.88 & 27.31 & -12.96 & 1.95 \\
Greece & -7.40 & 20.49 & -14.84 & -0.46
\end{tabular}

Source: Own calculations 
Figure B1: Retained earnings correction, official and corrected current account for Hong Kong

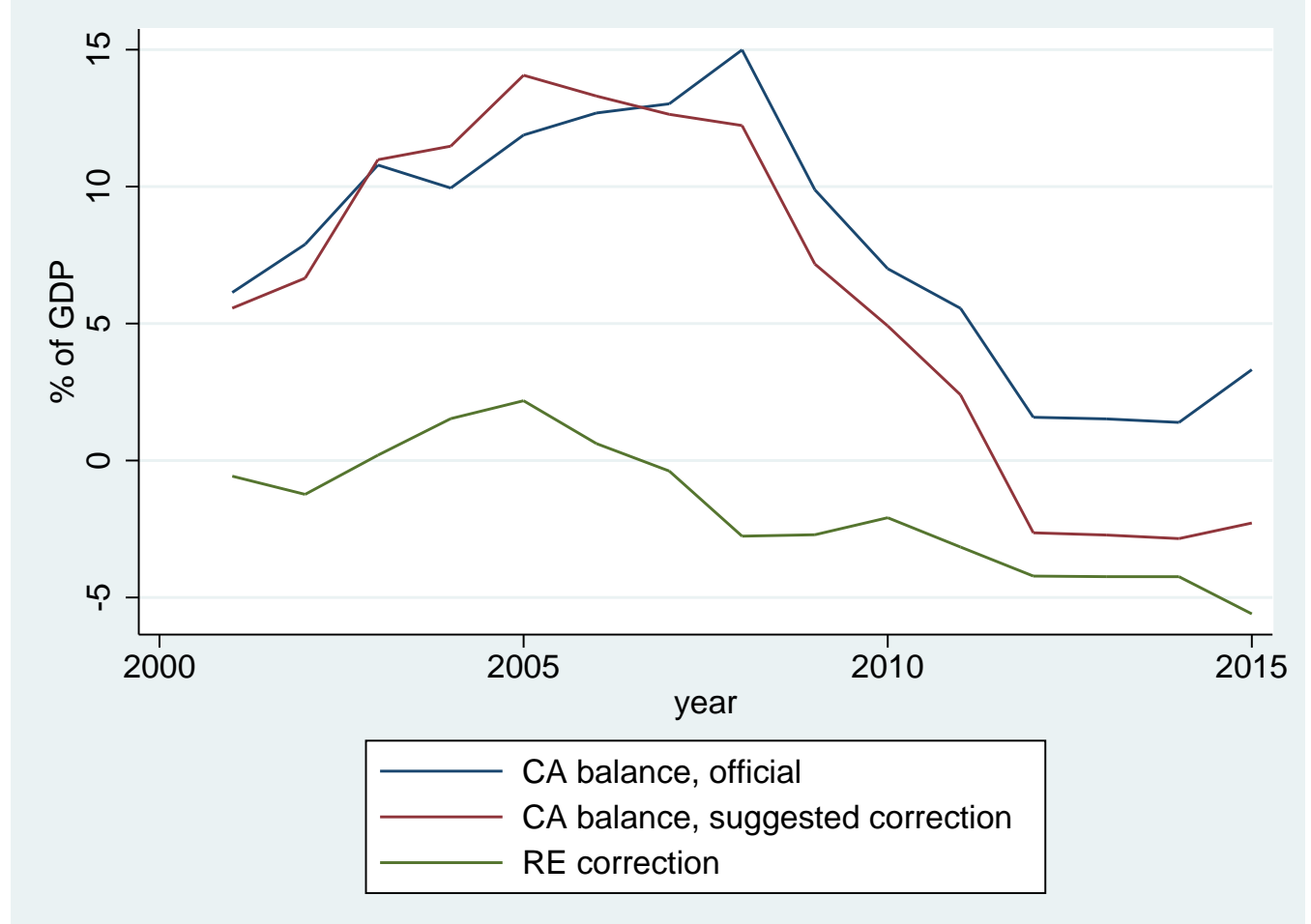

Source: IMF BOPS, own calculations

Note: Corrected current account balance is official current account plus the retained earnings correction. 
Figure B2: Retained earnings correction, official and corrected current account for Ireland

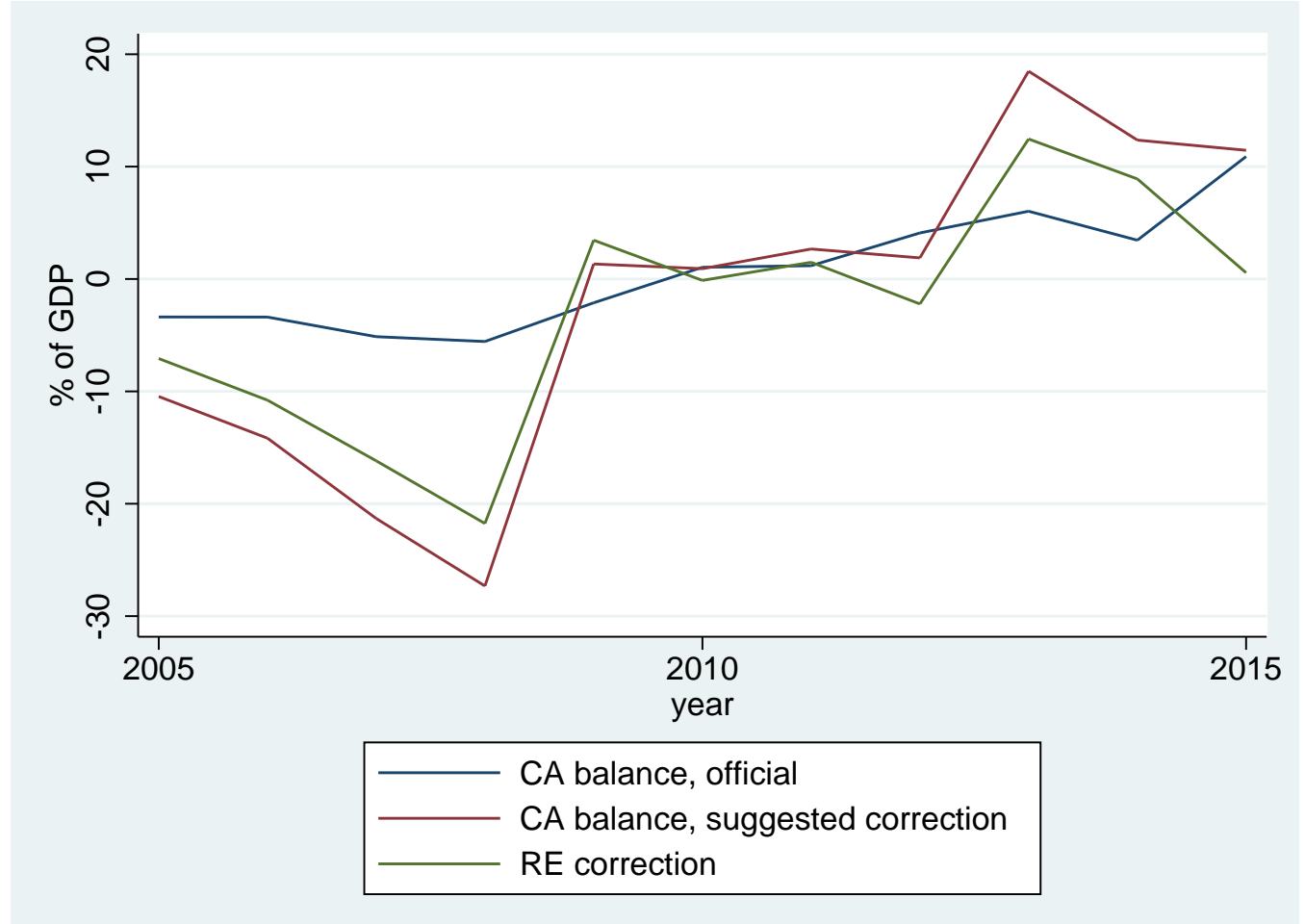

Source: IMF BOPS, own calculations

Note: Corrected current account balance is official current account plus the retained earnings correction. 
Figure B3: Retained earnings correction, official and corrected current account for Norway

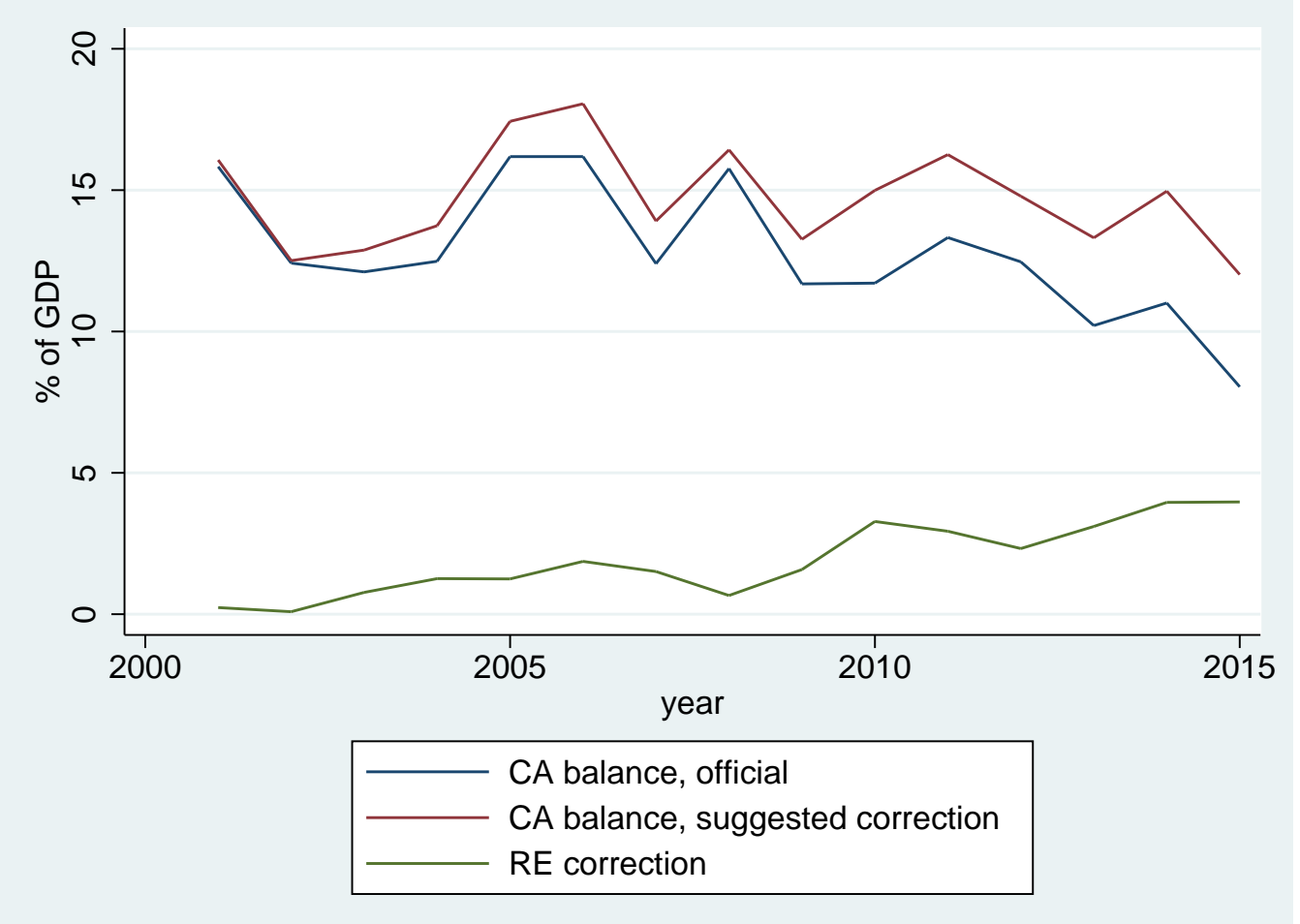

Source: IMF BOPS, own calculations

Note: Corrected current account balance is official current account plus the retained earnings correction. 
Figure B4: Retained earnings correction, official and corrected current account for Switzerland

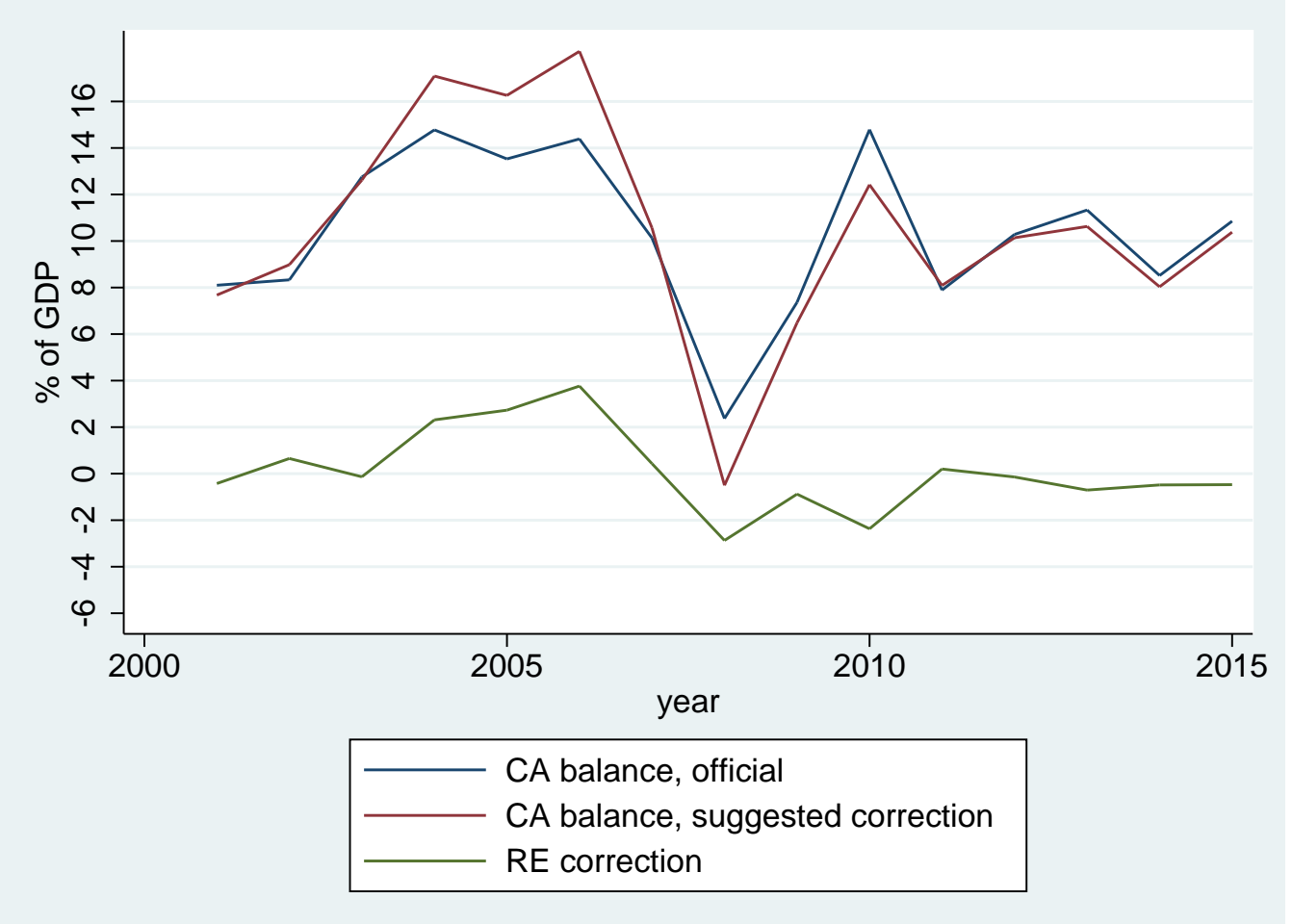

Source: IMF BOPS, SNB, own calculations

Note: Corrected current account balance is official current account plus the retained earnings correction. 
Table B3: Errors and omissions (EO) between official and corrected current account (\%GDP)

\begin{tabular}{|c|c|c|c|c|}
\hline & EO mean & EO corrected mean & EO absolute mean & EO corrected absolute mean \\
\hline Finland & 2.29 & 2.32 & 2.29 & $\begin{array}{l}2.32 \\
\end{array}$ \\
\hline Sweden & 2.18 & 2.80 & 2.18 & 2.80 \\
\hline Malaysia & 2.09 & 2.44 & 2.09 & 2.44 \\
\hline Norway & 2.08 & 4.00 & 2.08 & 4.00 \\
\hline Saudi Arabia & 1.90 & 2.28 & 1.90 & 2.28 \\
\hline Slovenia & 1.69 & 1.85 & 1.69 & 1.85 \\
\hline Ireland & 1.50 & -1.35 & 1.50 & 1.35 \\
\hline Russian Federation & 1.42 & -0.47 & 1.42 & 0.47 \\
\hline Venezuela & 1.33 & 1.16 & 1.33 & 1.16 \\
\hline Netherlands & 1.09 & 1.14 & 1.09 & 1.14 \\
\hline Denmark & 0.79 & 1.07 & 0.79 & 1.07 \\
\hline Philippines & 0.47 & 0.09 & 0.47 & 0.09 \\
\hline France & 0.42 & 0.55 & 0.42 & 0.55 \\
\hline Belgium & 0.36 & 1.46 & 0.36 & 1.46 \\
\hline Chile & 0.32 & 0.37 & 0.32 & 0.37 \\
\hline Germany & 0.30 & 0.36 & 0.30 & 0.36 \\
\hline Austria & 0.28 & 0.61 & 0.28 & 0.61 \\
\hline Indonesia & 0.28 & 0.04 & 0.28 & 0.04 \\
\hline Italy & 0.26 & 0.80 & 0.26 & 0.80 \\
\hline Argentina & 0.26 & 0.13 & 0.26 & 0.13 \\
\hline Ukraine & 0.10 & -0.41 & 0.10 & 0.41 \\
\hline Canada & 0.04 & 0.60 & 0.04 & 0.60 \\
\hline India & 0.00 & -0.18 & 0.00 & 0.18 \\
\hline Japan & -0.01 & -0.30 & 0.01 & 0.30 \\
\hline Brazil & -0.02 & -0.35 & 0.02 & 0.35 \\
\hline Australia & -0.03 & 0.36 & 0.03 & 0.36 \\
\hline Colombia & -0.05 & -0.05 & 0.05 & 0.05 \\
\hline United States & -0.05 & 0.14 & 0.05 & 0.14 \\
\hline South Africa & -0.09 & -0.19 & 0.09 & 0.19 \\
\hline Turkey & -0.22 & -0.27 & 0.22 & 0.27 \\
\hline Korea & -0.22 & -0.83 & 0.22 & 0.83 \\
\hline Poland & -0.33 & -0.38 & 0.33 & 0.38 \\
\hline Pakistan & -0.36 & -0.29 & 0.36 & 0.29 \\
\hline Hungary & -0.50 & -0.84 & 0.50 & 0.84 \\
\hline Switzerland & -0.55 & -0.44 & 0.55 & 0.44 \\
\hline New Zealand & -0.58 & -0.40 & 0.58 & 0.40 \\
\hline Hong Kong & -0.76 & -2.54 & 0.76 & 2.54 \\
\hline Spain & -0.78 & -0.98 & 0.78 & 0.98 \\
\hline Czech Republic & -0.89 & -1.18 & 0.89 & 1.18 \\
\hline Romania & -1.10 & -1.37 & 1.10 & 1.37 \\
\hline United Kingdom & -1.21 & -0.74 & 1.21 & 0.74 \\
\hline Israel & -1.48 & -0.46 & 1.48 & 0.46 \\
\hline Greece & -1.52 & -1.66 & 1.52 & 1.66 \\
\hline Portugal & -1.53 & -1.77 & 1.53 & 1.77 \\
\hline
\end{tabular}

Source: Own calculations 


\section{Robustness checks}

\section{C.1 Advanced economies only}

The first robustness check considers the effect of financial integration through the financial equity centers for the advanced economies. The sample is restricted to the 26 advanced economies for the first- and second-stage regressions. ${ }^{29}$ The results in Tables C1 and C2 show that the coefficient on the interaction term between the characteristics of the financial equity centers and the GAP variable is larger in absolute value for the reduced sample of advanced economies compared to the results shown for the full country sample in the paper.

\footnotetext{
${ }^{29}$ These countries are Australia, Austria, Belgium, Canada, Czech Republic, Denmark, Finland, France, Germany, Greece, Hong Kong, Ireland, Israel, Italy, Japan, Korea, the Netherlands, New Zealand, Norway, Portugal, Slovenia, Spain, Sweden, Switzerland, the United Kingdom, and the United States.
} 
Table C1: Medium-term current account models - advanced economies only

\begin{tabular}{|c|c|c|}
\hline & $\begin{array}{c}(1) \\
\text { Official }\end{array}$ & $\begin{array}{c}(2) \\
\text { Corrected }\end{array}$ \\
\hline Fiscal Balance (in deviation of trading partner average) & $\begin{array}{c}0.521^{*} \\
(0.215)\end{array}$ & $\begin{array}{c}0.594^{* *} \\
(0.209)\end{array}$ \\
\hline Old age dependency ratio (in deviation of trading partner average) & $\begin{array}{l}0.0399 \\
(0.206)\end{array}$ & $\begin{array}{c}0.238 \\
(0.256)\end{array}$ \\
\hline Population growth (in deviation of trading partner average) & $\begin{array}{l}-1.585 \\
(1.400)\end{array}$ & $\begin{array}{l}-2.096 \\
(1.891)\end{array}$ \\
\hline Lagged NFA as a ratio of GDP (Source: Lane and Milesi-Ferretti 2007) & $\begin{array}{c}0.0478^{* *} \\
(0.014)\end{array}$ & $\begin{array}{c}0.0483^{* *} \\
(0.014)\end{array}$ \\
\hline Oil balance only for Norway & $\begin{array}{c}0.157 \\
(0.170)\end{array}$ & $\begin{array}{c}0.265 \\
(0.173)\end{array}$ \\
\hline Oil balance except for Norway & $\begin{array}{l}-0.308 \\
(0.260)\end{array}$ & $\begin{array}{l}-0.148 \\
(0.278)\end{array}$ \\
\hline Output growth for emerging countries & $\begin{array}{c}-1.141^{* *} \\
(0.389)\end{array}$ & $\begin{array}{c}-1.081^{*} \\
(0.435)\end{array}$ \\
\hline Relative income (ratio of PC PPP GDP to the US level, 2000 USD) & $\begin{array}{l}0.0230 \\
(0.066)\end{array}$ & $\begin{array}{r}-0.0268 \\
(0.069)\end{array}$ \\
\hline Banking crisis dummy (Source: Laeven and Valencia 2012) & $\begin{array}{r}-0.0126 \\
(0.009)\end{array}$ & $\begin{array}{r}-0.0220 \\
(0.012)\end{array}$ \\
\hline Dummy for Asian Crisis from 1997 (1=Emerging Asian Country, 0=Other) & $\begin{array}{c}-0.00536 \\
(0.018)\end{array}$ & $\begin{array}{c}-0.00660 \\
(0.023)\end{array}$ \\
\hline Dummy for financial center (BEL, CHE, HKG, NLD) & $\begin{array}{l}0.0178 \\
(0.023)\end{array}$ & $\begin{array}{l}0.0346 \\
(0.024)\end{array}$ \\
\hline Dummy for euro introduction on Germany, Portugal, Spain, Greece & $\begin{array}{c}0.0412^{*} \\
(0.015)\end{array}$ & $\begin{array}{c}0.0483^{*} \\
(0.018)\end{array}$ \\
\hline Dummy for effect of aging on Germany, Switzerland, Italy, and Japan & $\begin{array}{l}-0.0000498 \\
\quad(0.018)\end{array}$ & $\begin{array}{l}-0.0104 \\
(0.023)\end{array}$ \\
\hline Constant & $\begin{array}{l}-0.0137 \\
(0.047)\end{array}$ & $\begin{array}{l}0.0231 \\
(0.050) \\
\end{array}$ \\
\hline $\begin{array}{l}\text { Observations } \\
\text { Adjusted } R^{2}\end{array}$ & $\begin{array}{c}201 \\
0.733\end{array}$ & $\begin{array}{c}201 \\
0.677\end{array}$ \\
\hline
\end{tabular}

Standard errors in parentheses

${ }^{*} p<0.05,{ }^{* *} p<0.01,{ }^{* * *} p<0.001$ 


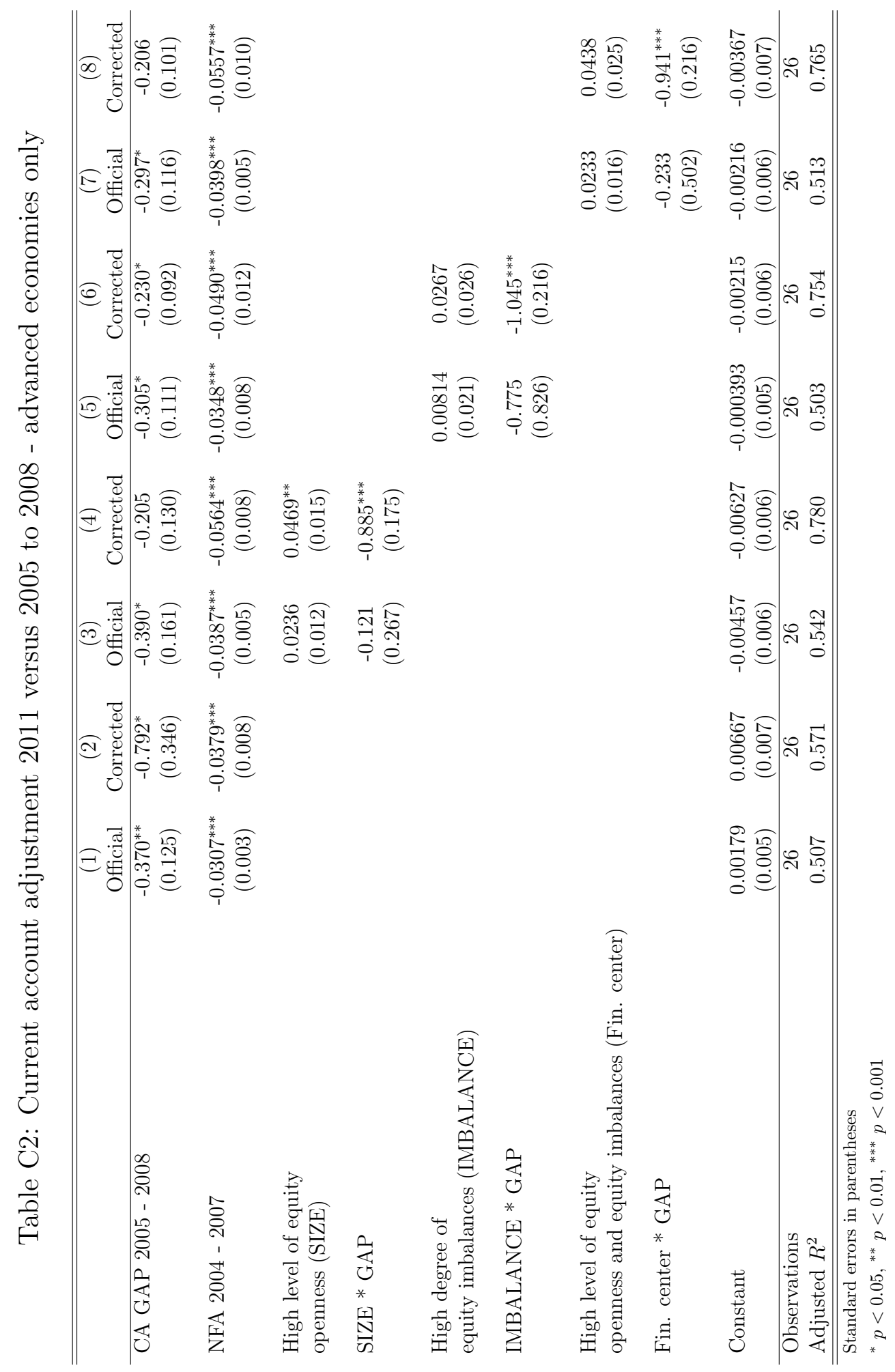




\section{C.2 Controlling for exchange rate regimes}

The second robustness check considers the effect of the peg dummy defined in Lane and Milesi-Ferretti (2012) for the full sample of 44 countries. The peg dummy is set to 1 for Austria, Belgium, Hong Kong, Denmark, Finland, France, Germany, Greece, Ireland, Italy, Netherlands, Portugal, Slovenia, Spain, and Saudi Arabia, and 0 otherwise.

The first-stage regressions are the same as those in Table 5 of the paper along with the second-stage regressions in columns 1 to 6 in Table C3. The regressions in columns 7 and 8 show that for the official current account and the corrected current account with RE, exchange rate regimes do not have a statistically significant effect for global adjustment. 


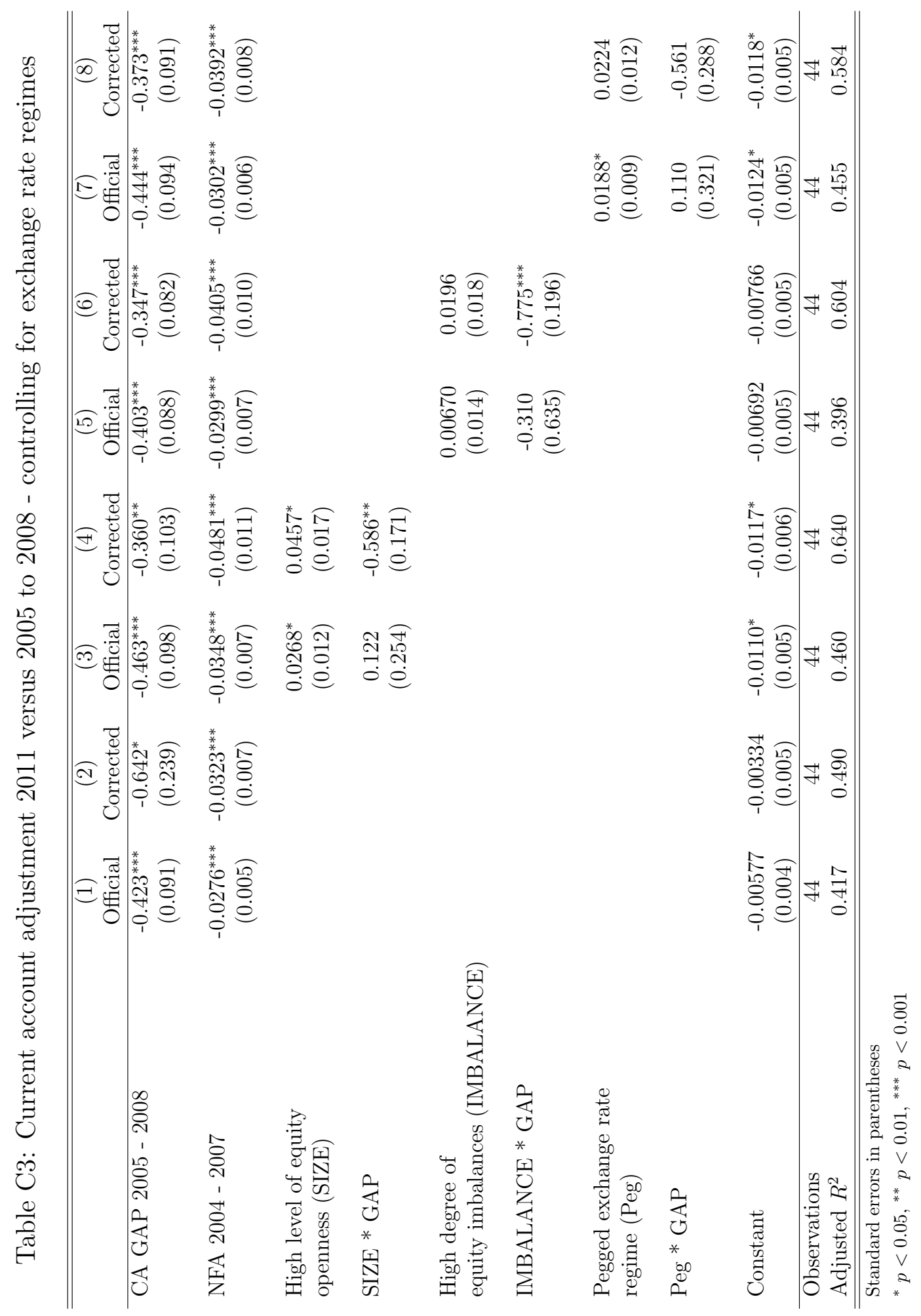




\section{Valuation changes and retained earnings}

CA balances and valuation changes lead to changes in the net international investment position (NIIP) according to the formula:

$$
\text { NIIP }_{i, t}=N I I P_{i, t-1}+C A \text { balance }_{i, t}+{\text { Valuation } \text { changes }_{i, t}}
$$

Valuation changes in the NIIP occur for various reasons. Missing retained earnings on portfolio equity investment in the compilation of official current account statistics, for example, lead to valuation changes that cannot be explained by current account developments. The mechanism is as follows: When companies do not distribute their profits but instead reinvest, stock prices increase. When stocks are held by non-residents, foreign liabilities increase. Thus retained earnings on portfolio equity investment lead to valuation changes due to asset price movements. Positive net retained earnings result in valuation gains in the NIIP.

While retained earnings are linked to asset price changes in portfolio equity, additional factors are also behind the evolution of the NIIP, such as price changes in other types of assets and exchange rate changes due to inflation differentials across countries. Furthermore, measurement issues, in the form of survey population and asset class adjustments as well as errors and omissions in the balance of payments statistics, also play an important role in the evolution of the NIIP. Due to lack of published data on valuation changes by countries, it is not possible to compare equity valuation changes in the IIP with the estimates of retained earnings at this point. 